UNIVERSITA' DEGLI STUDI DI BERGAMO

DIPARTIMENTO DI INGEGNERIA GESTIONALE

QUADERNI DEL DIPARTIMENTO ${ }^{\dagger}$

Department of Economics and Technology Management

Working Paper

n. $05-2011$

Determinants of total factor productivity in former Soviet Union economies: a stochastic frontier approach

by

Annageldy Arazmuradov, Gianmaria Martini, Davide Scotti

† Il Dipartimento ottempera agli obblighi previsti dall'art. 1 del D.L.L. 31.8.1945, n. 660 e successive modificazioni. 
NOTE

I Working Papers della Collana dei Quaderni del Dipartimento di Ingegneria Gestionale costituiscono un servizio atto a fornire la tempestiva divulgazione dei risultati dell'attività di ricerca, siano essi in forma provvisoria o definitiva.

I Working Papers della Collana sono pubblicati nell'archivio istituzionale dell'Università degli studi di Bergamo (Aisberg): http://dspace-unibg.cilea.it/handle/10446/370. 


\title{
Determinants of Total Factor Productivity in Former Soviet Union Economies: A Stochastic Frontier Approach
}

\author{
Annageldy Arazmuradov ${ }^{* \#}$, Gianmaria Martini ${ }^{\#}$, Davide Scotti ${ }^{\#}$ \\ \# Department of Economics and Management of Technology, University of Bergamo, Dalmine (BG), Italy \\ Submitted to World Development Journal on 27 September, 2011
}

\begin{abstract}
This paper investigates the process of GDP generation in Former Soviet Union (FSU) economies to provide understanding of the impact of technology channels on countries' efficiency. We apply a stochastic frontier approach to 15 FSU economies over the period 1995-2008, and we find that machinery imports and human capital improve a country's efficiency. Furthermore, we show that trade in capital goods and human capital also have a positive effect on total factor productivity (TFP), which, in turn, improves real GDP growth. Hence, our results suggest that FSU countries should improve public policies that provide incentives to invest in cross-country technology transfer and in domestic education in order to improve their economic growth. Additionally, our empirical evidence argues against the resource-curse hypothesis. We also show, by computing the efficiency change and technological change indices at the country level, that FSU economies are benefiting more from catching up to the best practice frontier than from exploiting technological progress.
\end{abstract}

JEL Classification: O33, O47, O57

Keywords: Eurasia, Former Soviet Union (FSU), Technology Channels, Total Factor Productivity (TFP), Stochastic Frontier Analysis

\footnotetext{
* Corresponding author: Department of Economics and Management of Technology, Faculty of Engineering, University of Bergamo, via Marconi 5, 24044 Dalmine (BG), Italy; Email : annageldy.arazmuradov@ unibg.it; Tel: (+39) 3271608071 .
} 


\section{Introduction}

Post-communist countries are challenged by complex tasks, which are, essentially, improving economic growth and reallocating resources to their best uses (Campos and Coricelli, 2002). This mandate is also pertinent to the fifteen former Soviet Union (FSU) economies. ${ }^{\mathrm{i}}$ FSU countries are transition economies with a considerable disparity in economic output. ${ }^{\text {ii }}$ As faster economic growth is achieved when countries' productivity is improved, there is a need to identify which channels help to increase it. However, no robust econometric studies have investigated the process of generating output across different FSU countries and its determinants. Previous contributions provide either single-country or agricultural studies estimating total factor productivity (TFP) through growth accounting and neoclassical production modeling (Zhang, 1997; De Broeck and Koen, 2000; Iradian, 2007), parametric stochastic frontier analysis (SFA) (Danilin et al., 1985; Delictas and Balcilar, 2005) or non-parametric data envelopment analysis (DEA) (Deliktas and Balcilar, 2005; Deliktas, 2008). These approaches present some drawbacks. Those applying the Solow residual (Solow, 1956) neoclassical approach assume that all countries operate on the efficient frontier and under constant returns to scale; these assumptions seem to be too restrictive. The SFA/DEA studies are applied to either a single sector or to a single country, and, above all, they do not investigate which factors affect countries' productivity. ${ }^{\text {iii }}$ This paper aims to fill these gaps by applying a stochastic frontier approach to FSU economies and by analyzing the impact of different technology-transfer channels on productivity.

Many previous contributions emphasize the importance of technology-transfer channels for improving economic growth, especially in developing countries such as FSU economies. They consider two technology-transfer channels: foreign direct investment (FDI) and trade in goods and services (Rivera-Batiz and Romer, 1991; Hoekman et al., 2004). ${ }^{\text {iv }}$ In this contribution, we consider FDI and, as a proxy for transferring technology through trade, the imports of machinery and equipment. Furthermore, we also consider human capital since the well-known contributions of economic growth theory (Nelson and Phelps, 1966; Romer, 1986, 1990; Lucas, 1988; Barro, 1991, 2001; Benhabib and Spiegel, 1994; Barro and Sala-i-Martin, 1995) point out the importance of the stock of human capital for economic growth. ${ }^{\mathrm{v}}$ Hence, our goal is to test the impact of these channels (i.e., FDI, imports of machinery and equipment, and human capital) on countries' efficiency levels by applying a time-varying stochastic production frontier model (Battese and Coelli, 1995) to a panel data set composed of 15 FSU countries over a 14-year period (1995-2008). We estimate a production frontier and compute countries' technical efficiency levels. This econometric approach allows us to compute yearly TFP growth at the country level and, through its decomposition into efficiency change (EC) and technical change (TC), to derive the second-order effects of technology-transfer channels on TFP.

These are our main results. First, we provide evidence that the amount of imported machinery and equipment has a positive impact on technical efficiency in FSU countries. Second, human capital is a crucial factor in increasing technical efficiency, both alone and when combined with imports of machinery and equipment. Third, we find that the effect of FDI on technical 
efficiency of FSU economies is not statistically significant. This result is different from that of Mastromarco and Ghosh (2009), who, however, did not investigate FSU countries. Fourth, we show that trade both in machinery and equipment and in human capital have a positive secondorder effect on TFP, through their positive first-order effect on the estimated countries' index of efficiency change (EC). The latter, in turn, has a positive and statistically significant effect on TFP. Fifth, given that the average efficiency change (EC) is positive and equal to $2.19 \%$ (yearly), while average technical change (TC) exhibits only a tiny positive increment $(0.29 \%$ yearly), we provide empirical evidence that FSU economies are more effective in catching up to the efficient frontier rather than in exploiting technological progress. Sixth, we find that FSU countries have positive TFP growth rates $(+2.37 \%$ yearly) for the 1995-2008 period, a much bigger estimate than those obtained in previously mentioned FSU studies. ${ }^{\text {vi }}$ Finally, we found no support for the resource-rich curse hypothesis: on the contrary, our results demonstrate a positive relationship between abundant resource possessions and economic development.

Our results yield the following policy implications. First, since openness to trade in capital goods exerts positive results on technical efficiency and, hence, on TFP, FSU countries should provide further incentives to facilitate terms of trade. Second, investments in education to raise labor capabilities are crucial for better absorbing foreign technology, especially for exploiting the benefits coming from imported foreign technology. ${ }^{\text {vi }}$

Our paper is closely related, to the best of our knowledge, with few previous contributions. Mastromarco and Ghosh (2009) were the first to analyze the impact of FDI, imported R\&D, imports of machinery and equipment, and human capital as channels of technology transfer in 57 developing countries in Africa, Asia, and Latin America during 1960-2000. ${ }^{\text {viii }}$ Deliktas and Balcilar (2005) studied 25 transition post-communist economies (including our sample countries) by using both stochastic frontier analysis (SFA) and data envelopment analysis (DEA) methods for the 1991-2000 period. However, they did not analyze the impact of technology channels on countries' productivity. Hence we extend these studies in several directions. First, we focus on technology channels, and we enlarge the time horizon up to 2008. Second, we decompose output growth into efficiency change, technical change, and TFP change. Third, we investigate the relation between country efficiency scores, TFP, and growth rates.

The paper is organized as follows. In Section II, the econometric model is presented and our research questions are stated. In Section III, we deliver our econometric results. Section IV concludes the paper. In the Appendix, we describe data sources and provide some further econometric results. 


\section{Econometric Model}

Technical efficiency refers to the ability to maximize outputs from a given vector of inputs or to minimize input utilization in the production process of a given vector of outputs (Coelli et al., 2005). Estimation is usually done by applying either a parametric approach (i.e., SFA) or a nonparametric approach (i.e., DEA).

The main advantage of SFA (see the seminal contributions by Aigner et al., 1977, and Meeusen and van den Broeck, 1977) is that, differently from DEA, it considers the possible influence of noise on the shape and positioning of the frontier, thanks to its two-component error term: a symmetric term $\left(\mathrm{v}_{\mathrm{it}}\right)$ representing noise and an asymmetric term $\left(\mathrm{u}_{\mathrm{it}}\right)$ accounting for technical efficiency. ${ }^{\text {ix }}$

Moreover, SFA easily allows the utilization of panel data and the incorporation of variables that are neither inputs to the production process nor outputs of it but which affect technical efficiency (Kumbhakar and Lovell, 2000).

Furthermore, the stochastic frontier approach is also more appropriate than the neoclassical growth-accounting technique, allowing introduction of shocks and unobserved cross-country effects in modeling, which is important on country-level studies. Moreover, SFA allows the estimation of the TFP change as the combination of its two main sources, which are technical change (i.e., the shift in the production function), and efficiency change (i.e., the movement toward or away from the frontier). On the contrary, the growth-accounting technique identifies technological progress in the Solow residual-i.e., the change of the output level that cannot be explained by input growth rates. Since no distinction is possible between technical and efficiency change, this would be reasonable only if all countries are producing on their frontier.

The stochastic frontier model could be expressed in case of countries' production functions as:

$$
Y_{i t}=f\left(L_{i t}, K_{i t}\right)+v_{i t}-u_{i t}
$$

where $Y_{i t}$ is the output observed at time $t$ of country $i, L_{i t}$ (labor) and $K_{i t}$ (capital) are the inputs observed at time $t$ of country $i$, and the term $\left(v_{i t}-u_{i t}\right)$ represents the composed error term. $v_{i t}$ are random variables that are assumed to be iid, $N\left(0, \sigma^{2}{ }_{v}\right)$, and independent of the $u_{i t} ; u_{i t}$ are assumed to be independently distributed as truncations at zero of the $N\left(m_{i t}, \sigma^{2}{ }_{u}\right)$ distribution and represent technical efficiency. Furthermore, it is possible to investigate the determinants of efficiency by applying a single-stage, maximum-likelihood estimation procedure. Kumbhakar et al. (1991) and Reifschneider and Stevenson (1991) propose stochastic frontier models in which the efficiency levels are expressed as an explicit function of a vector of determinants and a random error. In particular, we adopt the Battese and Coelli (1995) specification because it extends the model proposed by Kumbhakar et al. (1991) allowing the utilization of panel data. According to this model, efficiency is given by the following equation:

$u_{i t}=\delta \mathbf{z}_{i t}+\omega_{i t}$ 
where $z_{i t}$ is the vector of explanatory variables, $\delta$ is the vector of coefficient to estimate, and $\omega_{i t}$ is the error term. ${ }^{\mathrm{x}}$ Our main goal is to understand whether technological transfer channels can affect the GDP production through their effect on technical efficiency. Hence, we would like to test the following hypotheses.

Hypothesis \#1. Imports of machinery and equipment (IME) reduce technical inefficiency in an FSU country's production by enhancing its technological endowment.

Hypothesis \#2. Human capital (HC) plays a positive role as a facilitating channel of technology diffusion by reducing technical inefficiency in FSU economies.

Hypothesis \#3. Inward aggregate foreign direct investment (FDI) has a stimulating effect on countries' technical efficiency.

In order to test Hps. 1-3, the mean of the truncated normal representing the distribution of the inefficiency term $u_{\mathrm{it}}$ can be expressed, according to Eq. (2), as follows:

$u_{i t}=\alpha_{0}+\alpha_{1} F D I_{i t}+\alpha_{2} I M E_{i t}+\alpha_{3} H C_{i t}+\alpha_{13} H C^{\times} F D I_{i t}+\alpha_{23} H C^{\times} I M E_{i t}+\omega_{i t}$,

where FDI represents foreign direct investment, IME the imports of machinery and equipment, and $\mathrm{HC}$ the human capital stock. The variables $\mathrm{HC}^{\times}, \mathrm{FDI}$, and $\mathrm{HC}^{\times} \mathrm{IME}$ are interaction terms.

One important issue in the academic debate regarding developing countries is the so-called resource-curse hypothesis (Sachs and Warner, 1995, 2001). ${ }^{\mathrm{xi}}$ The latter comes from the observation that countries rich in natural resources tend to perform badly. The explanation for the curse is a crowding-out argument: there are some variables that drive economic growth and the developing countries' richness in natural resources crowds out such activities. For instance, natural resource abundance might crowd out innovation or entrepreneurial activities, which are economic growth drivers. We aim to test the resource-curse hypothesis for FSU economies, since some of them are rich in natural resources, mainly oil and gas. For this purpose, we divide our sample of FSU countries into two groups - resource-rich (RR) and non-resource-rich (NRR) ${ }^{\mathrm{xii}}$ and test the following hypothesis.

Hypothesis \#4. Resource-rich countries (RR) are less productive than non-resource-rich countries (NRR).

To investigate this hypothesis, we introduce a dummy variable in our estimated frontier: $\left(D_{r r}\right)$ is equal to 1 if the country is classified as resource-rich (RR) and 0 otherwise.

Following the approach of Mastromarco (2008) and Mastromarco and Ghosh (2009), we adopt a translog specification of the production function. Hence, the production function in Eq. (1) becomes as follows: 
$\ln \left(Y_{i t}\right)=\beta_{0}+\beta_{1} \ln \left(L_{i t}\right)+\beta_{2} \ln \left(K_{i t}\right)+\beta_{3} t+\beta_{4} D_{r r}+\frac{1}{2} \beta_{11} \ln \left(L_{i t}\right)^{2}+\frac{1}{2} \beta_{22} \ln \left(K_{i t}\right)^{2}+$

$\frac{1}{2} \beta_{33}(t)^{2}+\beta_{12} \ln \left(L_{i t}\right) \ln \left(K_{i t}\right)+\beta_{13} \ln \left(L_{i t}\right) t+\beta_{23} \ln \left(K_{i t}\right) t+v_{i t}-u_{i t}$.

Hence, we obtain the time-varying technical efficiency (TE) scores for country $i$ at time $t$ as follows:

$T E_{i t}=\exp \left(-u_{i t}\right)$

Technical efficiency change (EC) between period $t$ and period $t-1$ can be expressed as:

$E C_{i t}=\frac{T E_{i t}}{T E_{i t-1}}$.

According to Coelli et al. $(1998,2005)$, we compute the technical change (TC) index as the geometric mean between two consecutive years of partial derivatives of the production function with respect to time. ${ }^{\text {xiii }}$ Hence, we have:

$\mathrm{TC}_{\mathrm{it}}=\sqrt{\left[\left(1+f_{t}\left(Y_{i t}, L_{i t}, K_{i t}, t, \beta_{0}, \beta\right)^{\times}\left(1+f_{t-1}\left(Y_{i t-1}, L_{i t-1}, K_{i t-1}, t, \beta_{0}, \beta\right)\right]\right.\right.}$,

where $f_{\mathrm{t}}$ is the partial derivative of the translog production function with respect to time $t$, and $f_{\mathrm{t}}$ 1 is the partial derivative of the translog production function with respect to time $t-1$.

The estimation of TFP is essential in order to investigate empirically the role of the technologytransfer channels in explaining countries' productive performances. We compute it as the product of technical efficiency change and technological change (Seo et al., 2010):

$\mathrm{TFP}_{\mathrm{it}}=\mathrm{EC}_{\mathrm{it}}{ }^{\times} \mathrm{TC}_{\mathrm{it}}$.

We will analyze second-order effects of technology-transfer channels on countries' TFP. Their first-order effect on TE is estimated through Eqs. (2), (3), and (5). Hence, if we define $\partial T E / \partial z$ as the technology-transfer channel $z$ 's first-order effect on technical efficiency, we have that (from Eq. (5)):

$\frac{\partial T E}{\partial z}=-\frac{\partial u_{i t}}{\partial z} \times e^{-u_{i t}}$.

Hence, if for instance $\partial u_{i t} / \partial z<0$, then the factor $z$ increases country $i$ 's efficiency level.

From Eq. (6), we can write the following effect of $z$ on EC (after some simplifications and assuming negligible per-country changes in imports of transfer channels):

$\frac{\partial E C}{\partial z}=\frac{\partial T E_{t} / \partial z \times\left(T E_{t-1}-T E_{t}\right)}{\left(T E_{t-1}\right)^{2}}$.

Hence, from Eq. (10), the effect of a variation in transfer channel $z$ on EC is positive if the variation of TE as function of $z$ is positive (i.e., the sign of $\mathrm{Eq}(9)$ is positive) ${ }^{\mathrm{xiv}}$ This means that 
if TE increases as a function of $z, \mathrm{EC}$, in turn, also rises (i.e., the impact of a transfer channel $z$ on EC has the same sign as its effect on TE).

From Eq. (3), it is clear that time has no impact on the inefficiency scores and, hence, TC is not influenced by the transfer channels. We can then write the following expression to identify the impact of transfer channels on TFP (from Eq. (8)):

$\frac{\partial T F P}{\partial z}=\frac{\partial E C}{\partial z} \times T C+\frac{\partial T C}{\partial z} \times E C$

with $\partial T C / \partial z=0$, so that only the first term in the right-hand side of Eq. (11) matters. Hence, the impact of a transfer channel $z$ on TFP has the same sign as its effect on TE. We will test these effects empirically.

\section{Data}

We build up a panel of 15 FSU countries: Armenia (ARM), Azerbaijan (AZE), Belarus (BLR), Estonia (EST), Georgia (GEO), Kazakhstan (KAZ), Kyrgyzstan (KGZ), Lithuania (LTU), Latvia (LVA), Moldova (MDA), Russia (RUS), Tajikistan (TJK), Turkmenistan (TKM), Ukraine (UKR), and Uzbekistan (UZB). We consider the period 1995-2008 because the starting period is already 4 years later than 1991, when the FSU countries became independent from the USSR (ex-Soviet Union). This time spell was enough for market forces to play a role in macroeconomic stabilization (Bodenstein et al., 2003, p. 240). Our data source is derived from the UNCTAD database and World Bank Development Indicators online (2010). The sources and descriptions of data are presented in the Appendix at the end of the paper (Table A1). The sample is chosen following two criteria. First, all of the 15 included countries shared the same political and economic system under the Soviet Union before 1991. Second, we follow the principle of initial conditions introduced by de De Melo et al. (1997) and Blonigen and Wang (2004). ${ }^{\mathrm{xv}}$ Our empirical approach is a panel-data stochastic frontier analysis (Cornwell et al., 1990; Kumbhakar, 1990, 1991; Battese and Coelli, 1992; Simar, 1992; Hadri et al., 2003; and Greene, 2005).

The dependent variable representing the country's output level is the real GDP. The independent (input) variables of countries' production functions are physical capital (K) and labor force (L). Physical capital $\left(\mathrm{K}_{\mathrm{it}}\right)$ is measured in terms of accumulated capital according to the perpetual inventory method (PIM):

$K_{i t}=(1-\xi) K_{i t-1}+I_{i t}$,

where, $\xi$ is the depreciation rate set to $10 \%$ and $I_{i t}$ is real gross capital formation. ${ }^{\text {xvi }}$ The PIM method follows Chowdhury (2008), and the calibration of the depreciation rate is in line with $\mathrm{Bu}$ 
(2006), who analyzed seven developing countries. Labor $(L)$ is measured in terms of total labor force in millions.

We consider as technological transfer determinants of efficiency foreign direct investments (FDI), imports of machinery and equipment (IME), and human capital (HC). FDI is the aggregate foreign direct investments in the host country measured as percentage of incoming countries' GDP. Imports of machinery and equipment are measured in thousands of U.S. dollars. We specifically chose only IME, because transition economies had a weak technological basis and obtained new equipment from developed countries in the early years. HC is an index accounting for knowledge accumulation. According to Verdier (2008), it is measured in stock form in two steps as follows:

$$
\begin{aligned}
& H C_{i t}=\ln \left(\left(\frac{\rho_{i t}}{1+\eta_{i t}} \times(1+\gamma)-(1-\tau)\right)\right) \\
& \rho_{i t}=\ln \left(\left(P r Y r_{i t} \times P_{i t}+S d Y r_{i t} \times S_{i t}+H s Y r_{i t} \times \frac{H_{i t}}{\sum Y r_{i t}}\right)\right)
\end{aligned}
$$

where $\mathrm{P}_{\mathrm{it}}, \mathrm{S}_{\mathrm{it}}$, and $\mathrm{H}_{\mathrm{it}}$ mean, respectively, primary, secondary, and high school gross enrollment rates (according to Barro and Lee 1993, 2010), and $\mathrm{PrYr}_{\mathrm{it}}, \mathrm{SdYr}_{\mathrm{it}}$, and $\mathrm{HsYr}_{\mathrm{it}}$ are the years of schooling at primary, secondary, and high schools, which are different and varying for each country and each year. $\sum \mathrm{Yr}_{\mathrm{it}}$ is the sum of each year of schooling varying by country and year. $\eta_{i t}$ is the labor growth rate, $\gamma$ is the exogenous rate of technological progress set to $2 \%$, and $\tau$ is the depreciation rate of human capital. We calibrate it as equal to 5\%: this is slightly higher than the rate used in other contributions (e.g., Verdier, 2008) because FSU countries experience faster rates of human capital depreciation (Yegorov, 2009). ${ }^{\text {xvii }}$ Table 1 shows the descriptive statistics of the variables included in the analysis.

Table 1. Data Summary

\begin{tabular}{llccccc}
\hline Variable & \multicolumn{1}{c}{ Units } & Obs & \multicolumn{1}{c}{ Mean } & Std. Dev. & Min & Max \\
\hline RGDP & (million U.S.\$ ) & 210 & $29,420.13$ & $74,872.69$ & 715.7888 & $429,549.2$ \\
Labor & (million people) & 210 & $9,227.364$ & $18,085.34$ & 642.835 & $76,078.74$ \\
Capital & (millions U.S.\$) & 210 & $6.87 \mathrm{e}+10$ & $1.80 \mathrm{e}+11$ & $1.25 \mathrm{e}+09$ & $1.11 \mathrm{e}+12$ \\
FDI & (\% of GDP) & 210 & 27.21926 & 21.91189 & .3596927 & 140.4942 \\
IME & (thousands U.S.\$) & 210 & $4,142.572$ & $1.24 \mathrm{e}+07$ & 40.132 & $1.29 \mathrm{e}+08$ \\
HC & (index) & 210 & 46.5152 & 37.01572 & 22.76206 & 442.9474 \\
\hline
\end{tabular}

Note: RGDP - real gross domestic product), Labor - total labor force), Capital - accumulated capital stock), FDI aggregate inward foreign direct investment), IME - imports of machinery and equipment), and HC - accumulated human capital stock. Source: own calculations.

Notice that all variables have been divided by their geometric mean in order to avoid convergence problems. This means that coefficients of first-order regressors can be explained as output elasticities evaluated at the sample mean (Alvares et al., 2004). 


\section{Empirical Results and Discussion}

Table 2 shows the results of our econometric approach represented by Eqs. (2)-(4)-i.e., Model (1). Furthermore, for comparative purposes, we also ran a second model-i.e., Model (2) where factors affecting inefficiency and the resource-rich dummy are not considered. ${ }^{\text {xviii }}$ As far as Model (1) is concerned, notice that the relevant role of technical efficiency is confirmed by both the magnitude and the significance of $\gamma$-i.e., the parameter depending on the variability of the two components of the error term $\left(\gamma=\sigma^{2}{ }_{u} / \sigma^{2}\right)$ : a value of $\gamma=0.948$ implies that $94.8 \%$ of the distance from the frontier is explained by technical inefficiency. ${ }^{\text {xix }}$ This result confirms the importance of considering inefficiency in classical production functions. The relevant role of inefficiency was also confirmed by Model (2): again, $\gamma$ is statistically significant and very high. Furthermore, we also test the hypothesis of a Hicks-neutral production function with no technical change, and both hypotheses are rejected (see Table 3). ${ }^{\mathrm{xx}}$

Table 2. Efficiency Effects' Stochastic Frontier Results

\begin{tabular}{|c|c|c|c|c|c|}
\hline \multirow[b]{2}{*}{ Variable } & \multirow[b]{2}{*}{ Parameter } & \multicolumn{2}{|c|}{ Model 1} & \multicolumn{2}{|c|}{ Model 2} \\
\hline & & Estimate & St. Error & Estimate & St. Error \\
\hline Constant & $\beta_{0}$ & $0.2767 *$ & 0.1333 & $0.7460 * * *$ & 0.0924 \\
\hline $\ln (\mathrm{L})$ & $ß_{1}$ & $0.1695 *$ & 0.0818 & $0.5138 * * *$ & 0.0986 \\
\hline $\ln (\mathrm{K})$ & $\beta_{2}$ & $0.2412 *$ & 0.0952 & $0.2983 * * *$ & 0.0634 \\
\hline $\mathrm{t}$ & $\beta_{3}$ & 0.0305 & 0.0301 & -0.0138 & 0.0095 \\
\hline $\ln (\mathrm{L})^{2}$ & $\beta_{11}$ & $0.1564 *$ & 0.0702 & $-0.2533 * * *$ & 0.0746 \\
\hline $\ln L^{x} \ln K$ & $B_{12}$ & 0.0782 & 0.0537 & $0.1427 * * *$ & 0.0320 \\
\hline $\ln L^{x} t$ & $\beta_{13}$ & $-0.0134 \bullet$ & 0.0079 & $-0.0114 * *$ & 0.0040 \\
\hline $\ln (K)^{2}$ & $B_{22}$ & -0.0534 & 0.0540 & -0.0268 & 0.0384 \\
\hline $\ln K^{x} t$ & $\beta_{23}$ & $0.0174 * *$ & 0.0062 & 0.0054 & 0.0036 \\
\hline$t^{2}$ & $\beta_{33}$ & -0.0030 & 0.0030 & $0.0048 * * *$ & 0.0009 \\
\hline Dummy & $\mathrm{D}_{\mathrm{rr}}$ & $0.3330 * * *$ & 0.0563 & & \\
\hline $\mathrm{Z}$ intercept & $\alpha_{0}$ & 0.9166 *** & 0.1849 & & \\
\hline Z_FDI & $\alpha_{1}$ & -0.0377 & 0.0504 & & \\
\hline Z_IME & $\alpha_{2}$ & $-0.1552 *$ & 0.0660 & & \\
\hline Z_HC & $\alpha_{3}$ & $-0.5963 * * *$ & 0.1500 & & \\
\hline Z_HC ${ }^{\times}$FDI & $\alpha_{13}$ & $0.1989 * * *$ & 0.0552 & & \\
\hline $\mathrm{Z}_{\mathrm{H}} \mathrm{HC}^{\times} \mathrm{IME}$ & $\alpha_{23}$ & $-0.2529 * * *$ & 0.0572 & & \\
\hline Sigma $^{2}$ & $\sigma^{2}=\sigma_{v}^{2}+\sigma_{u}^{2}$ & $0.0794 * * *$ & 0.0063 & $1.1661 *$ & 0.4528 \\
\hline Gamma & $\gamma=\sigma_{u}^{2} / \sigma^{2}$ & $0.9480 * * *$ & 0.1126 & $0.9947 * * *$ & 0.0021 \\
\hline Log-Likelihood & $\operatorname{LogL}$ & 15.4591 & & 187.6503 & \\
\hline
\end{tabular}


logarithmic form, except the time variable ( $\mathrm{t}$ ). The second part of Table 2 shows the estimated coefficients for the z_variables ( $\alpha$ 's) representing inefficiency (Eq. 2). FDI-foreign direct investment (\% of GDP), IMEmachinery and equipment imports measured in thousands of U.S. dollars, and HC-accumulated human capital stock calculated according to formula (12). Source: own calculations.

Table 3. Tests for Hicks-Neutral Production Function and No Technical Change

\begin{tabular}{|c|c|c|c|c|c|}
\hline Null Hypothesis $\left(\mathbf{H}_{0}\right)$ & $\begin{array}{c}\text { Log- } \\
\text { Likelihood }^{\mathrm{a}}\end{array}$ & $\begin{array}{c}\text { Test } \\
\text { Statistic }(\lambda)^{b}\end{array}$ & $\begin{array}{c}\text { Critical } \\
\text { Value }(5 \%)^{\mathrm{c}}\end{array}$ & d.f. & Decision \\
\hline $\begin{array}{l}\mathrm{H}_{0} \text { Hicks-neutral production function } \\
\beta_{13}=\beta_{23}=0\end{array}$ & 18.962 & -7.016 & 5.138 & 2 & $\mathrm{H}_{0}$ rejected \\
\hline $\begin{array}{l}\mathrm{H}_{0}: \text { No technical change } \\
\beta_{13}=\beta_{23}=\beta_{33}=\beta_{3}=0\end{array}$ & 22.823 & -14.727 & 8.761 & 4 & $\mathrm{H}_{0}$ rejected \\
\hline \multicolumn{6}{|c|}{$\begin{array}{l}\text { Notes: }{ }^{a} \text { The magnitude to Log-Likelihood under } \mathrm{H}_{0},{ }^{b} \text { The test statistic } \lambda \text { was calculated by the following formula: - } \\
2 *\left[\operatorname{LogLikelihood}\left(\mathrm{H}_{0}\right)-\operatorname{LogLikelihood}\left(\mathrm{H}_{1}\right)\right] . \mathrm{H}_{0} \text { is the } \log \text {-likelihood from the restricted model and } \mathrm{H}_{1} \text { is the } \log \text { - } \\
\text { likelihood from Translog with non-neutral technical change. } \mathrm{H}_{1} \text { in our model is } 15.459 \text {. We reject the } \mathrm{H}_{0} \text { if our test } \\
\text { statistic is bigger than critical value. }{ }^{c} \text { Critical values were taken from Kodde and Palm (1986) for the } 5 \% \text { level of } \\
\text { significance. d.f. stands for degrees of freedom. Source: own calculations. }\end{array}$} \\
\hline
\end{tabular}

Looking at inputs' first-order coefficients of Model (1), we observe that both capital (K) and labor (L) are significant and have the expected positive sign. This means that, as expected and pointed out by previous works (Mastromarco, 2008; Mastromarco and Ghosh, 2009; Deliktas and Balcilar, 2005), they positively contribute to producing GDP. Notice that the greater magnitude of the accumulated capital stock $(\mathrm{K})$ with respect to labor (L) (0.24 versus 0.17$)$ may be related to the importance of gross domestic investments in FSU economies.

Concerning second-order and interaction coefficients, the variables that are statistically significant are labor $\left(L^{2}\right)$ and the interaction between capital and time. In Model (2) first-order coefficients are again statistically significant and greater in magnitude. This means that without considering the factors affecting inefficiency, we get an upward bias in the impact of inputs on GDP.

\subsection{Elasticities and Substitutability of Inputs}

According to Morrison et al. (2000), we compute the output elasticities from Eq. 3 (in order to obtain the percentage change in the output level due to a $1 \%$ increase in the input $j$ ) as follows:

$\varepsilon_{y, x_{j}}=\frac{\partial(\ln y)}{\partial\left(\ln x_{j}\right)}=\frac{\partial y}{\partial x_{j}} \times\left(\frac{x_{j}}{y}\right)$.

The variable $\varepsilon_{y, x_{j}}$ may be interpreted as an indicator of the returns to input $x_{j}$. This varies by observation and Table 4 only shows the average values across the sample. Notice that the elasticities for labor and capital have the expected positive sign that could be interpreted as their specific contribution to production. It is important to underline that the impact of capital on GDP in FSU countries is 10 times greater than the impact of labor. 
Table 4. Average Output Elasticity $\left(\mathrm{E}_{\mathrm{y}, \mathrm{X}}\right)$ and Substitutability $\left(\mathrm{Sub}_{\mathrm{lk}}\right)$ of Labor $(\mathrm{L})$ and Capital (K)

\begin{tabular}{|c|c|c|c|}
\hline Inputs & Labor $(\mathbf{L})$ & Capital (K) & Sub $_{\mathrm{lk}}$ of Labor (L) and Capital (K) \\
\hline $\boldsymbol{\varepsilon}_{\mathbf{y}, \mathbf{x}}$ & 0,0425 & 0,4064 & 0.1046 \\
\hline
\end{tabular}

Note: $\varepsilon_{y, x}$ is the average output elasticity with respect to inputs, labor (L), and capital (K). Sub $\mathrm{b}_{\mathrm{lk}}$ is the substitutability of labor and capital inputs from the below equation. Source: own calculations.

Moreover, since the marginal product of input $j$ is $M P_{j}=\frac{\partial y}{\partial x_{j}}=\frac{\partial(\ln y)}{\partial\left(\ln x_{j}\right)} \frac{y}{x_{j}}$ and the ratio between the marginal product of labor and the marginal product of capital reflects the slope of the isoquants in the labor-capital space (i.e., the marginal rate of substitution), the ratio between the elasticities of labor and capital can be interpreted as a normalized indicator of substitutability, as in Grosskopf et al. (1995):

$$
\operatorname{sub}_{L K}=\frac{M P_{L}}{M P_{K}} \times \frac{L}{K}=\frac{\varepsilon_{y L}}{\varepsilon_{y K}} .
$$

In our sample, the ratio between the average elasticities of labor and capital is equal to about 0.10 , meaning that one unit of labor is compensated, on average, by an extra 0.1 unit of capital.

\subsection{Technology Channels and Efficiency}

The results related to Model (1) also show the obtained empirical evidence regarding Hypotheses. \#1-4-i.e., on the determinants of technical efficiency and on the resource-curse hypothesis (Table 2). Notice that both imported machinery and equipment and human capital have negative, statistically significant coefficients. Hence, we provide evidence that they both have a positive impact on technical efficiency. This implies that Hypotheses \#1 and \#2 are positively verified. In contrast, the coefficient of FDI is not significant, which rejects our Hypothesis \#3.

Interestingly, $\mathrm{HC}$ has a greater impact on efficiency than IME. This result highlights the greater importance of human capital also for an efficient use of inputs.

As for the non-significance of FDI, this could be due to the fact that multinational enterprises (MNE) enjoy rents in nascent markets of FSU economies. Further possible explanations could be that foreign investors are vertically oriented and not targeted to local market services. These arguments are in line with the study of van Pottelsberghe de la Porterie and Lichtenberg (2001), who conclude that FDI investors tend to take advantage of the technology base of domestic markets rather than to diffuse the technological advantage. 
Last, notice that both interaction terms $\mathrm{HC}^{\times} \mathrm{FDI}$ and $\mathrm{HC}^{\times} \mathrm{IME}$ are statistically significant, but with opposite signs. The interaction between $\mathrm{HC}$ and FDI has a negative effect on efficiency, which could mean that the domestic human capital employed in foreign companies within FSU economies does not spread outside the necessary knowledge for a better use of inputs. On the other hand, the interaction term $\mathrm{HC}^{\times}$IME has a positive effect on efficiency. This is exactly the opposite of the previous result: if domestic human capital is employed to cooperate with imported capital goods in domestic activities, this allows the disclosure of a better use of inputs.

Regarding the well-known debate on the resource-curse hypothesis in developing countries, the dummy variable has a statistically significant and positive coefficient (see Table 2). This suggests that countries richly endowed with natural resources produce more GDP than nonresource-rich countries. Notice that, on average, resource-rich countries' technical efficiency is greater than that of non-resource-rich ones by $18.8 \%$ ( 0.63 versus 0.53 , Table 5 ). Hence, we reject also Hypothesis \#4. This means that we find support for rejecting the resource-curse hypothesis for FSU countries during the period 1995-2008, differently from previous contributions. $^{\text {xxi }}$

Table 5 displays the estimated technical efficiency (TE) scores according to Eq. (5), ranging from 0 to 1 (full efficiency-i.e., being on the production frontier). None of our sample economies are fully efficient. Table A2 in the Appendix also shows that on average technical efficiency has increased by about $21 \%$ from 1995 through 2008 . The mean efficiency for the whole sample over these years was $0.5633^{\text {xxii }}$, as indicated in Table 5 and in Fig. 1(a) (the mean of the continuous line). We also observe a gradual increase in technical efficiency after 2000 .

Table 5. Average Efficiency and TFP Decomposition for FSU Economies over 1995-2008

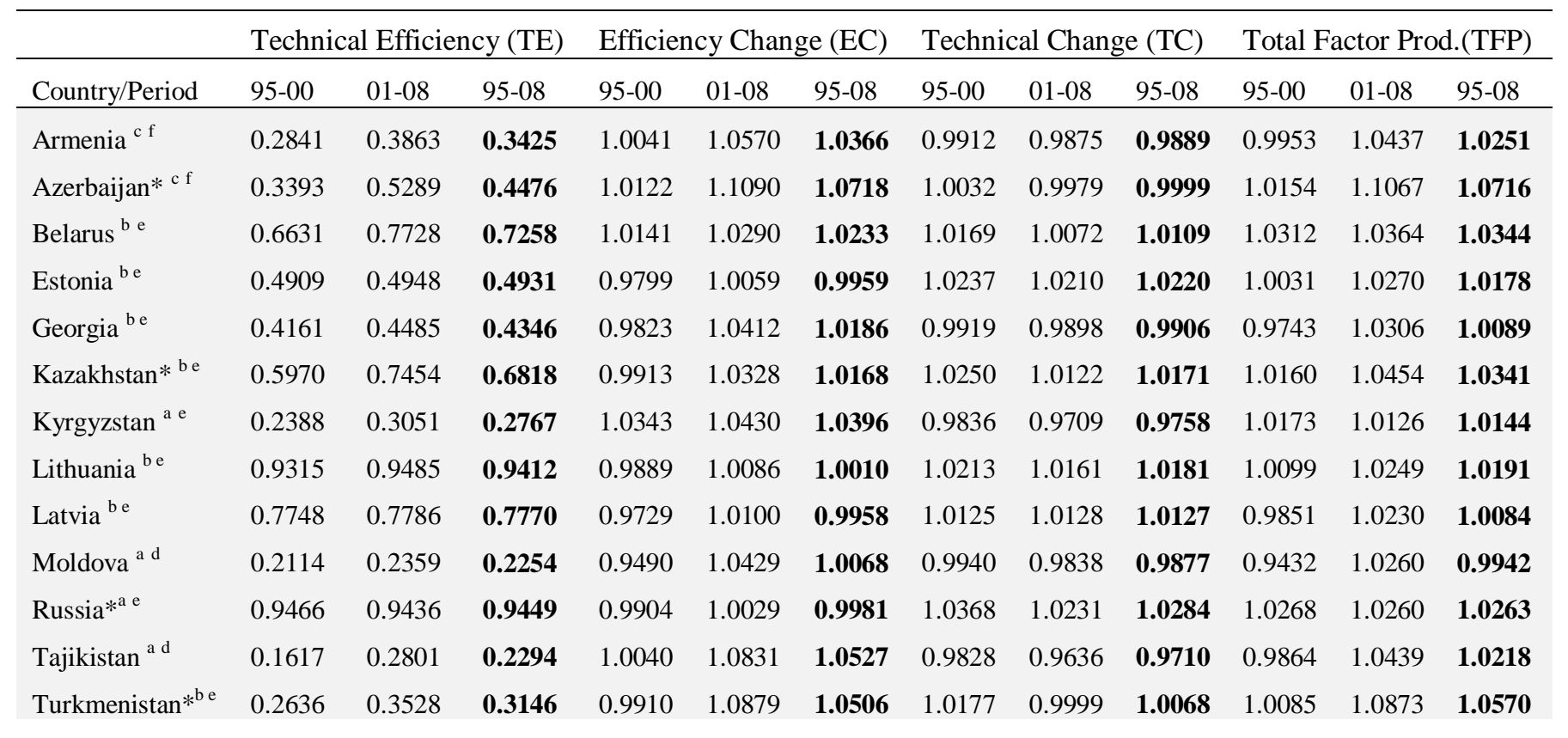




\begin{tabular}{lllllllllllllll} 
Ukraine $^{\text {a d }}$ & 0.7908 & 0.9020 & $\mathbf{0 . 8 5 4 3}$ & 0.9647 & 1.0280 & $\mathbf{1 . 0 0 3 7}$ & 1.0197 & 1.0053 & $\mathbf{1 . 0 1 0 8}$ & 0.9835 & 1.0336 & $\mathbf{1 . 0 1 4 3}$ \\
Uzbekistan*b $^{\text {b }}$ & 0.7050 & 0.8024 & $\mathbf{0 . 7 6 0 6}$ & 0.9774 & 1.0414 & $\mathbf{1 . 0 1 6 7}$ & 1.0007 & 0.9857 & $\mathbf{0 . 9 9 1 5}$ & 0.9780 & 1.0264 & $\mathbf{1 . 0 0 7 8}$ \\
\hline Mean A & 0.5210 & 0.5951 & $\mathbf{0 . 5 6 3 3}$ & 0.9904 & 1.0415 & $\mathbf{1 . 0 2 1 9}$ & 1.0081 & 0.9984 & $\mathbf{1 . 0 0 2 1}$ & 0.9983 & 1.0396 & $\mathbf{1 . 0 2 3 7}$ \\
\hline Mean RR* & 0.5703 & 0.6746 & $\mathbf{0 . 6 2 9 9}$ & 0.9925 & 1.0548 & $\mathbf{1 . 0 3 0 8}$ & 1.0167 & 1.0038 & $\mathbf{1 . 0 0 8 7}$ & 1.0089 & 1.0584 & $\mathbf{1 . 0 3 9 4}$ \\
Mean NRR & 0.4963 & 0.5553 & $\mathbf{0 . 5 3 0 0}$ & 0.9894 & 1.0349 & $\mathbf{1 . 0 1 7 4}$ & 1.0038 & 0.9958 & $\mathbf{0 . 9 9 8 9}$ & 0.9929 & 1.0302 & $\mathbf{1 . 0 1 5 8}$ \\
\hline
\end{tabular}

Note: The 95-08 stands for 1995-2008, which is average value for our estimation's time dimension. Mean A is the arithmetic mean of the sample. Mean $\mathrm{RR}^{*}$ is the arithmetic mean for the resource-rich group. Countries with asterisks (*) belong to the resource-rich group. Mean NRR is the non-resource-rich group countries' arithmetic mean. The superscripts a, b, c, d, e, and f are related to the real GDP growth groups and are presented in separate Table 8. Source: own calculations.

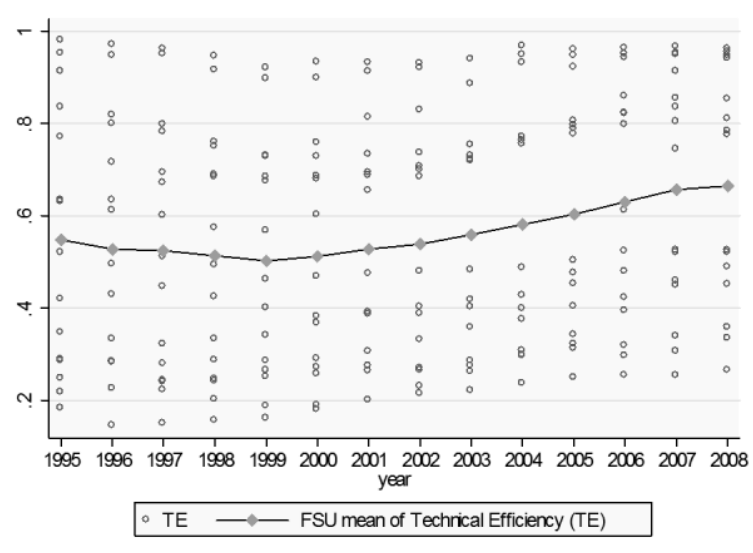

Fig. 1. Countries and average annual technical efficiency (TE) evolution for 15 FSU countries over 1995-2008. Source: own calculations.

According to the estimated technical efficiency scores, FSU countries that are close to Europe are more efficient than the ones closer to Asia, since on average, for the period 1995-2008, the leaders are Russia (94.4\%), Lithuania (94.1\%), Ukraine (85.4\%), and Latvia (77.7\%). Surprisingly, we observe an unexpected high level of efficiency from Uzbekistan (76.6\%), a country that is described as a controlled economy. In contrast, Moldova (22.5\%), Tajikistan (22.9\%), Kyrgyzstan (27.6\%), Turkmenistan (31.4\%), and Armenia (34.3\%) are the least efficient. $^{\text {xxiii }}$

For a more detailed benchmarking, countries' estimated efficiencies have been partitioned into two sub-periods - 1995-2000 and 2001-2008 - due to the fact that we observed the growth shift in technical efficiency scores in 2000 (see Fig. 1(a)). Notice that between these periods notable improvements in efficiency were demonstrated by Tajikistan (+73.2\%) and Azerbaijan $(+55.8 \%)$. Surprisingly, only a little increase in efficiency is observed for the Baltic States countries; for example, Latvia $(+0.49 \%)$, Estonia $(+0.79 \%)$, Lithuania $(+1.83 \%)$. Furthermore, we also observe some decreases: Russia has decreased by $-0.31 \%$. Interestingly, when we divide the sample into resource-rich (RR) ${ }^{\text {xxiv }}$ and non-resource-rich (NRR) countries we obtain some non-trivial results: on average for the whole period 1995-2008 the mean of TE for RR (0.6299) 
is higher than for NRR countries $(0.5300)$ by $18.84 \%$. Hence, this result provides further evidence to reject Hypothesis \#4. e

Table 5 also reports efficiency change (EC) (obtained according to Eq. (6)), technical change (obtained from Eq. (7)) and TFP (obtained from Eq. (10)) estimates. EC estimates represent the change in capacity utilization between two adjacent periods. On average, for the whole period FSU countries show an increase in their capacity utilization equal to $+2.19 \%$ yearly. Notice that, on average, RR countries are outperforming NRR ones: RR economies' average efficiency growth is $3.08 \%$, while for NRR countries it is only $1.74 \%$. The highest EC scores are achieved by Azerbaijan (7.2\%), Tajikistan (5.3\%), Turkmenistan (5.1\%), Kyrgyzstan (4.0\%) and Armenia (3.7\%). Surprisingly, countries that are close to Europe and have better business environments are lagging behind. For example, Estonia (-0.41\%), Latvia (-0.42\%), and Russia (-0.19\%) perform better in terms of technical efficiency but display a negative efficiency change. Columns 7-9 of Table 5 display the TC estimates. The average value for all FSU countries is 1.0021, meaning a technological progress equal to $+0.21 \%$. Eight countries show progress, on average, for the period 1995-2008: Belarus, Estonia, Lithuania, Latvia, Russia, Ukraine, Kazakhstan, and Turkmenistan. The rest of the countries displayed technological regress. Furthermore, RR economies performed much better on average $(\mathrm{TC}=1.0087)$ than NRR ones, since the latter had no technological progress $(\mathrm{TC}=0.9989$ ). However, if we look at sub-periods, we can see that negative (i.e., lower than 1) average values are brought due to the fact that many countries performed worse after 2000. All of the countries (with the exception of Latvia) show a decrease in the technical change index in the period 2000-2008.

The last three columns of Table 5 show the estimated TFP indexes. On average, for the whole sample period, we find positive TFP growth mainly due to a robust increase of efficiency change $(+2.19 \%)$ rather than in technical change $(+0.21 \%)$. Only Moldova shows very small negative ($0.58 \%$ ) regress in TFP, because negative technical change outweighed positive efficiency change. Moldova's fall in TFP on average could be attributed to negative technical change or using different technologies. Again, we reject our Hypothesis \#4, since RR economies perform better than NRR ones. They show a positive growth rate in TFP equal to 3.94\%, much higher than that of NRR countries, which is equal to $1.58 \%$. If we look at sub-periods, during the period 1995-2000 only eight countries demonstrate positive productivity growth, but after 2000 until 2008 all 15 FSU economies have positive TFP indexes.

Figure 2 shows that the distribution of TE, EC, TC, and TFP estimates over the observed period, using box-plot diagrams. It is evident that the distributions of EC, TC, and TFP are much narrower with respect to the distribution of TE scores. 


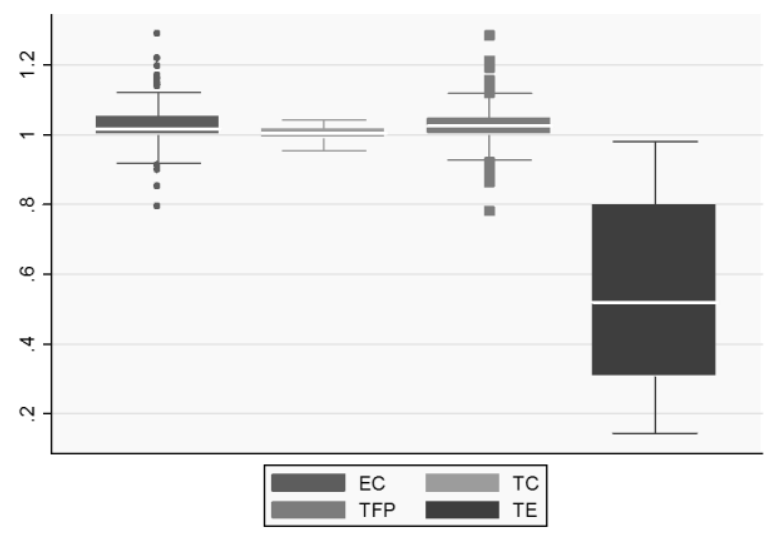

Fig. 2. Distributions of TE, EC, TC, and TFP scores for 15 FSU countries over 1995-2008. Source: own calculations.

Table 6 shows that the mean of RR countries in all productivity indexes is always higher than that of NRR countries. Moreover, their mean differences are statistically significant, with the exception of EC.

Table 6. Mean Difference Tests for Resource-Rich (RR) and Non-Resource-Rich (NRR) Groups

\begin{tabular}{|c|c|c|c|c|c|c|c|c|c|}
\hline Over & Mean & Std. Err & {$[95 \%$} & Conf. Interval] & Over & Mean & Std. Err & \multicolumn{2}{|c|}{ 95\% Conf. Interval] } \\
\hline TE & & & & & $\mathrm{TC}$ & & & & \\
\hline$N_{R}{ }^{* a b}$ & 0.5300 & .0223 & 4853 & .5762 & $\mathrm{NRR}^{* \mathrm{ab}}$ & 0.9989 & .0016 & .9957 & 1.0020 \\
\hline $\mathrm{RR}$ & 0.6299 & .0293 & .5723 & 6917 & $\mathrm{RR}$ & 1.0087 & .0019 & 1.0050 & 1.0125 \\
\hline $\mathrm{EC}$ & & & & & TFP & & & & \\
\hline NRR & 1.0174 & .0042 & 1.0086 & 1.0262 & $\mathrm{NRR}^{* \mathrm{~b}}$ & 1.0158 & .0041 & 1.0078 & 1.0239 \\
\hline $\mathrm{RR}$ & 1.0308 & .0087 & 1.0137 & 1.0480 & $\mathrm{RR}$ & 1.0392 & .0081 & 1.0235 & 1.0552 \\
\hline
\end{tabular}

Note: TE-technical efficiency, EC-efficiency change, TC-technical change, and TFP-total factor productivity. RR stands for the resource-rich countries group, and NRR is the non-resource-rich countries. ${ }^{a}$ Kruskal-Wallis equalityof-populations rank tests: * is the statistically significant difference between the RR and NRR groups of countries. TE- chi-squared $=6.731$ with 1 d.f. and prob. $=0.0095 ;$ EC- chi-squared $=0.022$ with 1 d.f. and prob. $=0.8824$; TCchi-squared $=10.591$ with 1 d.f. and prob. $=0.0011$; chi-squared $=3.204$ with 1 d.f. and prob. $=0.0735$. ${ }^{\mathrm{b}}$ Two sample $\mathrm{t}$-tests on means with unequal variances: TE- $\mathrm{t}=-2.7111$ and $\operatorname{Pr}(|\mathrm{T}|>|\mathrm{t}|)=0.0075 ; \mathrm{EC}-\mathrm{t}=-1.3743$ and $\operatorname{Pr}$ $(|\mathrm{T}|>|\mathrm{t}|)=0.1725$; TC- $\mathrm{t}=-3.9685$ and 0.0001; TFP- $\mathrm{t}=-2.6047$ and $\operatorname{Pr}(|\mathrm{T}|>|\mathrm{t}|)=0.0106$. Source: own calculations. Source: own calculations.

\subsection{Correlation Between Productivity Indexes and GDP Growth}

In this subsection, we observe whether there is any correlation between the estimated productivity indexes and countries' real GDP and real GDP growth. The aim is to investigate whether there is a significant impact of productivity on GDP. The results are presented in Table 7, reporting variables' correlation measured using the Pearson, Kendall, and Spearman indexes (the latter two being non-parametric). 
We find that real GDP is not correlated to productivity indexes. The association between real GDP growth and TFP is instead positive and statistically significant and equal to +0.87 (Pearson's rho). From this, we could conclude that TFP could explain differences in real output growth in FSU economies. Moreover, our results report high positive association $(+0.84)$ between real GDP growth and EC. Non-parametric tests of Spearman and Kendall corroborate our findings. Notice, that TFP has a slightly stronger relation with real GDP growth than EC. If TFP is an important factor for economic growth, then FSU economies should focus on channels that improve TFP. In Eqs. (9)-(10) we have shown that factors affecting technical efficiency also matter for TFP (and with the same sign). This implies that FSU countries should focus on transfer channels and human capital in order to sustain their economic growth.

We find a very high significant positive correlation (+0.95) between EC and TFP. Furthermore, TC is significantly negatively associated with EC (-0.36 (Pearson)). It seems that in FSU countries there is a sort of tradeoff between technical change (TC) and efficiency change (EC).

Table 7. Pairwise Correlations of Real GDP, Real GDP Growth and Efficiency Scores ${ }^{\mathrm{xxv}}$

\begin{tabular}{lcccccc}
\hline & & rGDP & rGDPgr & EC & TC & TFP \\
\hline rGDP & Pearson's rho & 1.0000 & & & & \\
rGDPgr & & 0.0175 & 1.0000 & & & \\
EC & & -0.0147 & $0.8420^{*}$ & 1.0000 & & \\
TC & & 0.1188 & -0.0962 & $-0.3583^{*}$ & 1.0000 & \\
TFP & & 0.0234 & $0.8710^{*}$ & $0.9490^{*}$ & -0.0461 & 1.0000 \\
\hline rGDP & Kendall's tau & 1.0000 & & & & \\
rGDPgr & & -0.0446 & 1.0000 & & & \\
EC & & -0.0278 & $0.5684^{*}$ & 1.0000 & & \\
TC & & 0.0044 & -0.0876 & $-0.3162^{*}$ & 1.0000 & \\
TFP & & -0.0121 & $0.6160^{*}$ & $0.7249^{*}$ & -0.0411 & 1.0000 \\
\hline rGDP & Spearman's rho & 1.0000 & & & & \\
rGDPgr & & -0.0641 & 1.0000 & & & \\
EC & & -0.0395 & $0.7578^{*}$ & 1.0000 & & \\
TC & & 0.0059 & -0.1205 & $-0.4648^{*}$ & 1.0000 & \\
TFP & & -0.0204 & $0.8048^{*}$ & $0.8838^{*}$ & -0.0616 & 1.0000 \\
\hline
\end{tabular}

Note: rGDP is the real gross domestic product; GDPgr is the real GDP growth rates, EC is efficiency change, TC is technical change, and TFP is total factor productivity. The results reported at the $1 \%(0.01)$ significance level with significant correlations are marked with an asterisk (*). Source: The data for rGDP and rGDPgr variables are from the UNCTAD database and own calculations.

Table 8 shows the partition of FSU countries according to real GDP growth. Countries are divided according to output growth into three groups: slow (GDP $<4.0 \%$ ), medium (GDP 4.0$8.0 \%$ ) and high (GDP > 8.0\%) growers. We have already mentioned that real GDP growth and TFP are positively correlated. 
Table 8. Real GDP growth and Efficiency Scores.

\begin{tabular}{|c|c|c|c|c|c|c|c|c|c|c|c|c|}
\hline \multirow[b]{2}{*}{ Country/Period } & \multicolumn{3}{|c|}{ Technical Efficiency (TE) } & \multicolumn{3}{|c|}{ Efficiency Change (EC) } & \multicolumn{3}{|c|}{ Technical Change (TC) } & \multicolumn{3}{|c|}{ Total Factor Prod.(TFP) } \\
\hline & $95-00$ & $01-08$ & $95-08$ & $95-00$ & $01-08$ & $95-08$ & $95-00$ & $01-08$ & $95-08$ & $95-00$ & $01-08$ & $95-08$ \\
\hline $\mathrm{GDP}^{\mathrm{a}}<2.5 \%$ & 0.4699 & 0.5334 & 0.5061 & 0.9885 & 1.0400 & 1.0202 & 1.0034 & 0.9893 & 0.9947 & 0.9915 & 1.0284 & 1.0142 \\
\hline $\mathrm{GDP}^{\mathrm{b}} 2.5-5.0 \%$ & 0.6052 & 0.6680 & 0.6411 & 0.9872 & 1.0321 & 1.0148 & 1.0137 & 1.0056 & 1.0087 & 1.0008 & 1.0376 & 1.0234 \\
\hline $\mathrm{GDP}^{\mathrm{c}}>5.0 \%$ & 0.3117 & 0.4576 & 0.3951 & 1.0081 & 1.0830 & 1.0542 & 0.9972 & 0.9927 & 0.9944 & 1.0053 & 1.0752 & 1.0483 \\
\hline $\mathrm{GDP}^{\mathrm{d}}<4.0 \%$ & 0.3880 & 0.4727 & 0.4364 & 0.9725 & 1.0513 & 1.0210 & 0.9988 & 0.9842 & 0.9898 & 0.9711 & 1.0345 & 1.0101 \\
\hline $\mathrm{GDP}^{\mathrm{e}} 4.0-8.0 \%$ & 0.6027 & 0.6593 & 0.6350 & 0.9922 & 1.0303 & 1.0156 & 1.0130 & 1.0039 & 1.0074 & 1.0050 & 1.0340 & 1.0228 \\
\hline $\mathrm{GDP}^{\mathrm{f}}>8.0 \%$ & 0.3117 & 0.4576 & 0.3951 & 1.0081 & 1.0830 & 1.0542 & 0.9972 & 0.9927 & 0.9944 & 1.0053 & 1.0752 & 1.0483 \\
\hline
\end{tabular}

Note: We grouped countries on (slow, medium, high) GDP growth for our sample period, 1995-2008: GDP ${ }^{\mathrm{d}}<4.0 \%$ is the arithmetic mean for the countries with GDP growth rate less than 4.0\%; GDP ${ }^{\mathrm{e}} 4.0-8.0 \%$ is the arithmetic mean for the countries with GDP growth rate from 4.0\%-8.0\%; and GDP ${ }^{\mathrm{f}}>8.0 \%$ is the arithmetic mean for the countries with GDP growth rate higher than 8.0\%. Additionally, we checked GDP growth rates for the period1993-2008, due to the fact that we started computing accumulated the physical capital (K) variable from 1993 and wanted to see its effects. GDP ${ }^{a}<2.5 \%$ is the arithmetic mean for the countries with GDP growth rate less than $2.5 \%$; GDP ${ }^{\mathrm{b}} 2.5-$ $5.0 \%$ is the arithmetic mean for the countries with GDP growth rate from $2.5 \%-5.0 \%$; and GDP ${ }^{\mathrm{c}}>5.0 \%$ is the arithmetic mean for the countries with GDP growth rate higher than 5.0\%. Source: own calculations.

Figure 3 confirms the observed relationship between TFP and economic growth. The dotted line fitting the observations has a positive relationship. This result confirms for FSU economies the previous empirical evidence stressing the importance of TFP in explaining the differences in the growth of countries' outputs (Klenow and Rodriguez-Clare, 1997; Hall and Jones, 1999; Hsieh and Klenow, 2010). They point out the need for identifying the drives of TFP. We have found that in FSU economies both human capital and imports of machinery and equipment increase countries' TFP. 


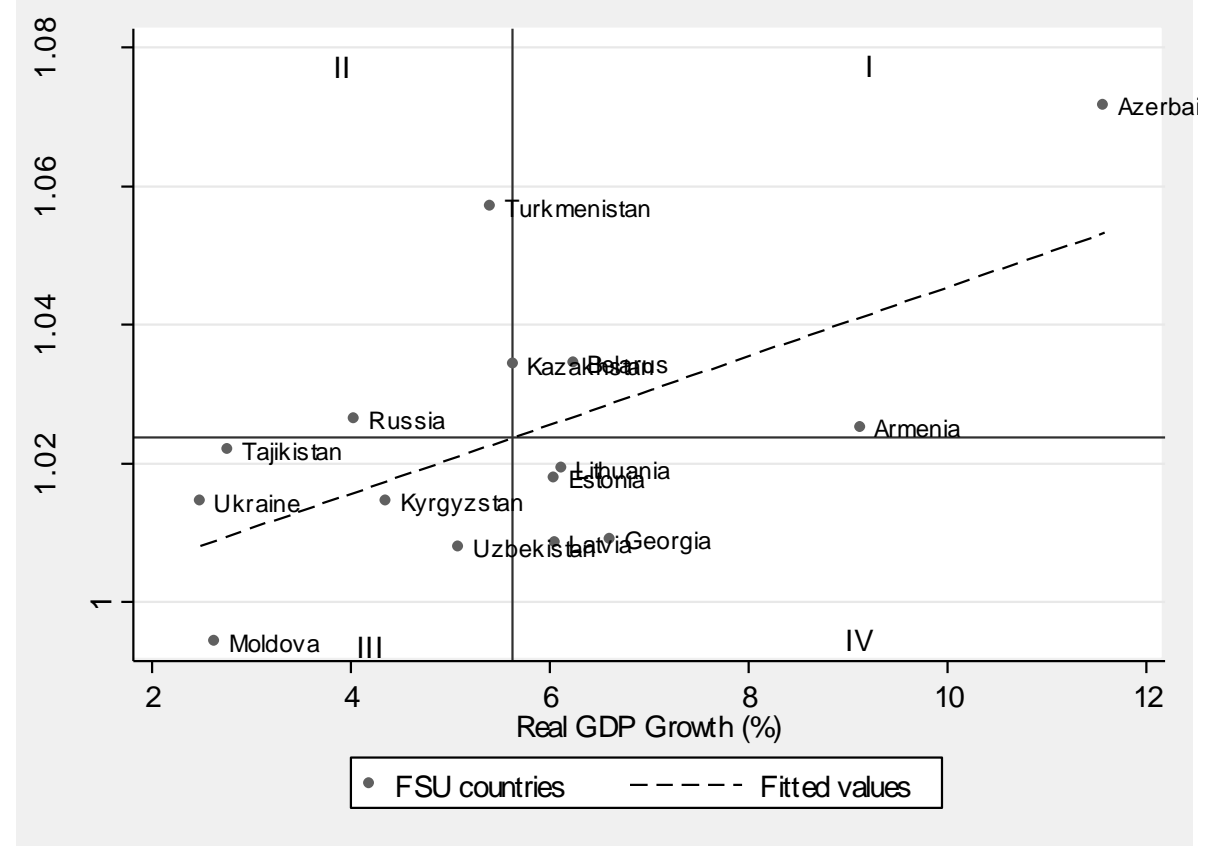

Note: Quadrant I: Armenia, Azerbaijan, Belarus, Kazakhstan; Quadrant II: Kazakhstan, Russia, Turkmenistan; Quadrant III: Kyrgyzstan, Moldova, Tajikistan, Ukraine, Uzbekistan; Quadrant IV: Georgia, Estonia, Lithuania, Latvia. Source: authors' calculations.

Fig.3. TFP and real GDP growth rate tradeoff matrix for FSU countries for 1995-2008.

\section{Conclusion}

In this paper, we contribute to the literature on technology channels' effects on economic growth by investigating the process of GDP production in 15 former Soviet Union economies by applying a time-varying, stochastic-frontier-analysis efficiency model in order to investigate the effects on productivity of technology diffusion channels (FDI and imports of machinery and equipment) and of human capital. We found that there still exists room for improving the utilization of inputs in FSU economies. However, all these countries show, on average, a positive rise in efficiency during the observed period.

Our empirical results demonstrate that both the import of machinery and equipment and human capital have a positive influence on technical efficiency of FSU countries. Furthermore, we demonstrate also that these variables exert a positive effect on total factor productivity thanks to the influence they exert on efficiency change, which was found to be a crucial determinant (much more than technical change) of total factor productivity index growth in our sample. Moreover, we find that the value of knowledge capital could be further improved if combined with foreign capital trade and investments. 
Furthermore, differently from many previous contributions, we did not observe the presence of the resource-curse hypothesis. On the contrary, we revealed the presence of a positive relationship between natural resource abundance and economic growth in FSU economies after the breaking up of the former Soviet Union.

Our statistical analysis points out an important positive relation between real GDP growth and TFP. Hence, since human capital and trade in capital goods are factors positively affecting TFP, governments of FSU countries should implement policies to improve domestic human capital and facilitate trade in capital goods. We found support for the ideas of Klenow and RodriguezClare (1997), Hall and Jones (1999), and the recent study by Hsieh and Klenow (2010), who underline the importance of TFP in explaining countries' output growth.

Moreover, we think that launching market-oriented reforms, selective openness to foreign interventions, and following free trade policies could dramatically assist most of the FSU countries in reaching their best potential output. Similar conclusions for post-communist economies have been made by Kolodko $(2005,2009)$ for the case of Poland, the first country embracing a market economy among post-communist systems.

\section{References}

Aghion, P., Howitt, P., 1992. A model of growth through creative destruction. Econometrica 60(2), 323-351.

Aigner, D., Lovell, K., Schmidt, P., 1977. Formulation and estimation of stochastic frontier production function models. Journal of Econometrics 6, 21-37.

Alvares, M.A, Arias, C., Greene, H.G., 2004. Accounting for unobservables in production models: Management and inefficiency," Economic Working Papers at Centro de Estudios Andaluces from Centro de Estudios Andaluces, No. E2004/72.

Atkinson, S., Cornwell, C., 1994. Estimation of output and input technical efficiency using a flexible functional form and panel data. International Economic Review 35(1), 245-255.

Atkinson, S., Cornwell, C., 1994a. Parametric estimation of technical and allocative inefficiency with panel data. International Economic Review 35(1), 231-243.

Barrell, R., Holland, D., 2000. Foreign direct investment and enterprise restructuring in central Europe. Economics of Transition, 8(2), 477-504.

Barro, R.J., 1991. Economic growth in a cross section of countries. The Quarterly Journal of Economics, 106(2), 407-443.

Barro, R.J., 2001. Human capital and growth. The American Economic Review 91(2), 12-17.

Barro, R.J., Lee, J-W., 1993. International comparisons of educational attainment. Journal of Monetary Economics 32, 363-394. 
Barro, R.J., Lee, J-W., 2010. A new data set of educational attainment in the world, 1950-2010. NBER Working Paper No. 15902.

Barro, R.J., Sala-i-Martin, X., 1995. Economic Growth. New York: McGraw-Hill.

Battese, G., Coelli, T., 1992. Frontier production functions, technical efficiency and panel data: With application to paddy farmers in India. Journal of Productivity Analysis 3, 153-169.

Battese, G., Coelli, T., 1995. A model for technical inefficiency effects in a stochastic frontier production model for panel data. Empirical Economics 20, 325-332.

Becker, G.S., 1975. Human Capital: A Theoretical and Empirical Analysis, with Special Reference to Education. NBER Books, 2nd ed., National Bureau of Economic Research, Inc., number beck75-1, July.

Benhabib, J., Spiegel, M., 1994. The role of human capital in economic development evidence from aggregate cross-country data. Journal of Monetary Economics 34(2), 143-173.

Blonigen, B.A., Wang, M., 2004. Inappropriate pooling of wealthy and poor countries in empirical fdi studies. NBER Working Paper No. w10378.

Blomström, M., Kokko, A., Globerman, S., 2001. The determinants of host country spillovers from foreign direct investment: A review and synthesis of the literature. In Pain, Nigel (ed.) (2001) Inward Investment, Technological Change and Growth. Basingstoke: MacMillan.

Bodenstein, T., Plümper, T., Schneider, G., 2003. Two sides of economic openness: Non-tariff barriers to trade and capital controls in transition countries, 1993-2000. Communist and PostCommunist Studies 36, 231-243.

Borensztein, E., De Gregorio, J., Lee, J., 1998. How does foreign direct investment affect economic growth? Journal of International Economics 45(1), 115-135.

Brunnschweiler, C.N., 2008. Cursing the blessings? Natural resource abundance, institutions, and economic growth. World Development 36(3), 399-419.

Brunnschweiler, C.N., Bulte, E.H., 2008. The resource curse revisited and revised: A tale of paradoxes and red herrings. Journal of Environmental Economics and Management 55(3), 248264.

Bu, Y., 2006. Fixed capital stock depreciation in developing countries: Some evidence from firm level data. Journal of Development Studies 42(5), 881-901.

Bulte, E.H., Damania, R., Deacon, R.T., 2005. Resource intensity, institutions, and development. World Development 33, 1029-1044.

Büthe, T., 2008. The politics of foreign direct investment into developing countries: Increasing fdi through international trade agreements? American Journal of Political Science 52(4),741762. 
Calderón, C., Poggio V., 2010. Trade and economic growth: Evidence on the role of complementarities for CAFTA-DR countries. Policy Research Working Paper 5426. World Bank.

Campos, N.F., Coricelli, F., 2002. Growth in transition: What we know, what we don't, and what we should. Journal of Economic Literature 40(3), 793-83.

Chowdhury, S.D., 2008. Perpetual inventory method. Economic \& Labour Market Review 2 (9), 48-52.

Coelli, T.J., Rao D.S.P., Battese G.E., 1998. An Introduction to Efficiency and Productivity Analysis. Boston: Kluwer Academic Publishers.

Coelli, T.J., Rao D.S.P., O’Donnel, C.J., Battese G.E., 2005. An Introduction to Efficiency and Productivity Analysis, $2^{\text {nd }}$ edition. New York: Springer.

Cornwell, C., Schmidt P., Sickles R., 1990. Production frontiers with cross sectional and time series variation in efficiency levels. Journal of Econometrics 46, 185-200.

Danilin, V.I., Materov, I.S., Rosefielde, S., Lovell C.A.K., 1985. Measuring enterprise efficiency in the Soviet Union: A stochastic frontier analysis. Economica, New Series 52(206), 225-233.

De Broeck, M, Koen, V., 2000. The great contractions in Russia, the Baltics and the other countries of the former Soviet Union: A view from supply side. IMF Working Paper 32.

Deliktas, E., 2008. The comparison of technical efficiency and productivity growth in transition countries and the Soviet Union countries, 2008. In: Proceedings of International Conference on Emerging Economic Issues in a Globalizing World. Izmir, 2008, p. 92.

Deliktas, E., Balcilar, M., 2005. A comparative analysis of productivity growth, catch-up, and convergence in transition economies. Emerging Markets Finance and Trade 41(1), 6-28.

De Melo, M., Denizer, C., Gelb, A., Tenev, S., 1997. Circumstance and choice: The role of initial conditions and policies in transition economies. Policy Research Working Paper 1866, World Bank.

Denison, E.F., 1962. The Sources of Economic Growth in the United States and the Alternatives Before Us, CED Supplementary Paper No. 13, Committee for Economic Development, New York

Dunning, J.H., 1993. Multinational Enterprises and the Global Economy. New York: AddisonWesley.

Dunning, J.H., 1998. Globalization, Trade and Foreign Direct Investment. UK: Elsevier Science.

Eaton, J., Kortum, S., 2001. Trade in capital goods. European Economic Review 45, 1195-1235.

Ellingstad, M., 1997. The Maquiladora syndrome: Central European prospects. Europe-Asia Studies 49(1), 7-22. 
Førsund, F.R., Lovell, C.A.K., Schmidt, P., 1980. A survey of frontiers production functions and of their relationship to efficiency measurement. Journal of Econometrics 13, 5-25.

Greene, W., 2005. Reconsidering heterogeneity in panel data estimators of the stochastic frontier model. Journal of Econometrics 126, 269-303.

Grosskopf, S., Margaritas, D., Valdmanis, V., 1995. Estimating output substitutability of hospital services: A distance function approach. European Journal of Operational Research 80, 575-587.

Grossman, G., Helpman, E., 1991. Trade, knowledge spillovers, and growth. European Economic Review 35(2-3), 517-526.

Grossman, G., Helpman,E., 1993. Innovation and Growth in the Global Economy. Cambridge, MA: MIT Press.

Hadri, K., Guermat, C., Whittaker, J., 2003. Estimation of technical inefficiency effects using panel data and doubly heteroskedastic stochastic production frontiers. Empirical Economics 28, 203-222.

Hall, R., Jones, C., 1999. Why do some countries produce so much more output per worker than others? Quarterly Journal of Economics 114, 1-39.

Hoekman, B.M., Maskus, K.E., Saggi, K., 2004. Transfer of technology to developing countries: Unilateral and multilateral policy options. Working Paper PEC2004-0003, Institute of Behavioral Science, University of Colorado at Boulder.

Hsieh, C-T., Klenow, P.J., 2010. Development accounting. American Economic Journal: Macroeconomics 2010, 2(1), 207-223.

Iradian, G., 2007. Rapid growth in transition economies: Growth-accounting approach. IMF Working Paper 164.

Jensen, C., 2006. Foreign direct investment and economic transition: Panacea or pain killer? Europe-Asia Studies 58(6), 881-902.

Keller, W., 2004. International technology diffusion. Journal of Economic Literature 42, 752782.

Klenow, P., Rodriguez-Clare, A., 1997. The neoclassical revival in growth economics: Has it gone too far? NBER Macroeconomic Annual, B. Bernanke and J.Rotemberg, eds., Cambridge, MA: MIT Press, pp. 73-114.

Kneller, R., 2005. Frontier technology, absorptive capacity and distance. Oxford Bulletin of Economics and Statistics 67(1), 1-23.

Kneller, R., Stevens, P., 2006. Frontier technology and absorptive capacity: Evidence from OECD manufacturing industries. Oxford Bulletin of Economics and Statistics 68, $1-21$. 
Kodde, D., Palm, F., 1986. Wald criteria for jointly testing equality and inequality restrictions. Econometrica 54(5), 1243-1248.

Kolodko, G.W., 2005. Lessons for the emerging markets from Poland's great change. Communist and Post-Communist Studies 38(39), 369-379.

Kolodko, G.W., 2009. A two-thirds success. Poland's post-communist transformation 19892009. Communist and Post-Communist Studies 42, 325-351.

Konings, J., 2001. The effects of foreign direct investment on domestic firms, Economics of Transition, 9(3), 619-633.

Kumbhakar, S., 1990. Production frontiers and panel data, and time varying technical inefficiency. Journal of Econometrics 46, 201-211.

Kumbhakar, S., 1991. Estimation of technical inefficiency in panel data models with firm- and time-specific effects. Economics Letters 36, 43-48.

Kumbhakar, S.C., Ghosh, S., McGuckin, J.T., 1991. A generalized production frontier approach for estimating determinants of inefficiency in U.S. dairy firms. Journal of Business \& Economic Statistics 9(3), 279-286.

Kumbhakar, S., Lovell, C.A. K., 2000. Stochastic Frontier Analysis. New York: Cambridge University Press.

Lipsey, R.E., 2002. Home and host country effects of FDI. NBER Working Papers, 9293.

Lucas, R.E., 1988. On the mechanics of economic development. Journal of Monetary Economics 22(1), 3-42.

Mastromarco, C., 2008. Foreign capital and efficiency in developing countries. Bulletin of Economic Research 60(4), 327-427.

Mastromarco, C., Ghosh, S., 2009. Foreign capital, human capital, and efficiency: A stochastic frontier analysis for developing countries. World Development 37 (2), 489-502.

Meeusen, W., van den Broeck, J., 1977. Efficiency estimation from Cobb-Douglas production functions with composed error. International Economic Review 18, 435-444.

Mincer, J., 1958. Investment in human capital and personal income distribution. Journal of Political Economy 66(4), 281-302.

Morrison, C.J., Johnston W.E., Frengley G.A.G., 2000. Efficiency in New Zealand sheep and beef farming: The impacts of regulatory reform. The Review of Economics and Statistics 82(2), $325-337$.

Murshed, S.M., Serino, L.A., 2011. The pattern of specialization and economic growth: The resource curse hypothesis revisited. Structural Change and Economic Dynamics 22, 151-161. 
Navaretti, G.B., Venables, A.J., 2004. Multinational Firms in the World Economy. Princeton, NJ: Princeton University Press.

Nelson, R., Phelps, E., 1966. Investment in humans, technological diffusion and economic growth. American Economic Review 56(1/2), 69-75.

Neumayer, E., 2004. Does the "resource curse"' hold for growth in genuine income as well? World Development 32(10), 1627-1640.

Nishimuzi, M., Page, J.M., 1982. Total factor productivity growth, technical progress and technical efficiency change: Dimensions on productivity change in Yugoslavia 1965-78. Economic Journal 92(368), 920-936.

Nunnenkamp, P., 2004. To what extent can foreign direct investment help achieve international development goals? The World Economy 27(5), 657-677.

Parente, S.L., Prescott, E.C., 1994. Barriers to technology adoption and development. Journal of Political Economy 102, 298-321.

Reifschneider, D., Stevenson, R., 1991. Systematic departures from the frontier: A framework for the analysis of firm inefficiency. International Economic Review 32, 715-723.

Rivera-Batiz, L.A., Romer, P.M., 1991. International trade with endogenous technological change. European Economic Review 35(4), 971-1001.

Romer, P.M., 1986. Increasing returns and long-run growth. Journal of Political Economy, 94(5), 1002-1037.

Romer, P.M., 1990. Endogenous technological change. Journal of Political Economy 98(5), Part 2, S71-S102.

Sachs, J.D., Warner, A.M., 1995. Natural resource abundance and economic growth. NBER Working Paper, no. 5398.

Sachs, J.D., Warner, A.M., 2001. Natural resources and economic development: The curse of natural resources. European Economic Review 45, 827-838.

Schmidt, P., Sickles R.C., 1984. Production frontiers and panel data. Journal of Business \& Economic Statistics 2(4), 367-374.

Seo, D., Featherstone, A.M., Weisman, D.L., Gao, Y., 2010. Market consolidation and productivity growth in U.S.wireline telecommunications: Stochastic frontier analysis vs. Malmquist index. Review of Industrial Organization 36(3), 271-294.

Schultz, T.W., 1960. Capital formation by education. Journal of Political Economy 68, 571-583.

Simar, L., 1992. Estimating efficiencies from frontier models with panel data: A comparison of parametric, nonparametric, and semiparametric methods with bootstrapping. Journal of Productivity Analysis 3, 167-203. 
Solow, R., 1956. A contribution to the theory of economic growth. Quarterly Journal of Economics 70(1), 65-94.

Stijns, J.P., 2005. Natural resource abundance and economic growth revisited. Resources Policy 30, 107-130.

Stijns, J.P., 2006. Natural resource abundance and human capital accumulation. World Development 34(6), 1060-1083.

van Pottelsberghe de la Potterie, B., Lichtenberg F., 2001. Does foreign direct investment transfer technology across borders? Review of Economics and Statistics 83, 490-497.

Verdier, G., 2008. What drives long-term capital flows? A theoretical and empirical investigation. Journal of International Economics 74, 120-142.

Xu, B., 2000. Multinational enterprises, technology diffusion, and host country productivity growth. Journal of Development Economics 62, 477-493.

Yegorov, I., 2009. Post-Soviet science: Difficulties in the transformation of the R\&D systems in Russia and Ukraine. Research Policy 38, 600-609.

Zhang, B., 1997. Total factor productivity of grain production in the former Soviet Union. Journal of Comparative Economics 24, 202-209. 


\section{APPENDIX}

Table A.1. Data Description and Sources

\begin{tabular}{|c|c|c|c|c|}
\hline Variable & Description & Units & Source & Accessed \\
\hline $\begin{array}{l}\text { Translog } \\
\text { Model } \\
\text { RGDP }\end{array}$ & $\begin{array}{l}\text { Real gross domestic product in } \\
\text { U..S dollars at constant prices } \\
\text { (2000) and constant exchange } \\
\text { rates (2000) per capita }\end{array}$ & $\begin{array}{l}\text { Millions } \\
\text { USD }\end{array}$ & $\begin{array}{l}\text { UNCTAD, } \\
\text { http://unctadstat.unctad.org/ReportFold } \\
\text { ers/reportFolders.aspx?sCS_referer=\&s } \\
\text { CS_ChosenLang=en }\end{array}$ & 06.02 .11 \\
\hline $\begin{array}{l}\text { Labor } \\
\text { (L) }\end{array}$ & Total labor force in a country & Thousands & $\begin{array}{l}\text { UNCTAD, } \\
\text { http://unctadstat.unctad.org/ReportFold } \\
\text { ers/reportFolders.aspx?sCS_referer=\&s } \\
\text { CS_ChosenLang=en }\end{array}$ & 06.02 .11 \\
\hline $\begin{array}{l}\text { Capital } \\
\text { (K) }\end{array}$ & $\begin{array}{l}\text { Accumulated capital stock } \\
\text { measured by perpetual } \\
\text { inventory method (PIM) }\end{array}$ & $\begin{array}{l}\text { Millions } \\
\text { USD }\end{array}$ & $\begin{array}{l}\text { UN Statistics Division, } \\
\text { http://unstats.un.org/unsd/snaama/introd } \\
\text { uction.asp }\end{array}$ & 21.02.11 \\
\hline $\begin{array}{l}\text { Inefficiency } \\
\text { Model }\end{array}$ & & & & \\
\hline FDI & $\begin{array}{l}\text { Years. Code is } 1-1995 . .14-2008 \\
\text { Aggregate foreign direct } \\
\text { investment into FSU economies }\end{array}$ & $\begin{array}{l}\text { Years } \\
\text { Percentage } \\
\text { of gross } \\
\text { domestic } \\
\text { product }\end{array}$ & $\begin{array}{l}\text { UNCTAD, } \\
\text { http://unctadstat.unctad.org/ReportFold } \\
\text { ers/reportFolders.aspx?sCS_referer=\&s } \\
\text { CS_ChosenLang=en }\end{array}$ & 06.02 .11 \\
\hline IME & $\begin{array}{l}\text { Imports of machinery and } \\
\text { transport equipment (SITC 7) }\end{array}$ & $\begin{array}{l}\text { Thousands } \\
\text { USD }\end{array}$ & $\begin{array}{l}\text { UNCTAD, } \\
\text { http://unctadstat.unctad.org/ReportFold } \\
\text { ers/reportFolders.aspx?sCS_referer=\&s } \\
\text { CS_ChosenLang=en }\end{array}$ & 06.02 .11 \\
\hline $\mathrm{HC}$ & $\begin{array}{l}\text { Accumulated human capital } \\
\text { stock. }\end{array}$ & Units & $\begin{array}{l}\text { World Bank and authors' calculations } \\
\text { http://data.worldbank.org/data- } \\
\text { catalog/world-development-indicators }\end{array}$ & 18.02.11 \\
\hline $\mathbf{D}_{\mathrm{rr}}$ & $\begin{array}{l}\text { Dummy variable for the } \\
\text { resource-rich countries; } 1= \\
\text { resource-rich: } 0=\text { otherwise }\end{array}$ & 1,0 & Authors & 01.03 .11 \\
\hline
\end{tabular}


Table A.2. Technical Efficiency (TE) Scores for the FSU Countries

\begin{tabular}{|c|c|c|c|c|c|c|c|c|c|c|c|c|c|c|c|c|c|}
\hline TE & 1995 & 1996 & 1997 & 1998 & 1999 & 2000 & 2001 & 2002 & 2003 & 2004 & 2005 & 2006 & 2007 & 2008 & $1995-2000$ & 2001-2008 & Mean A \\
\hline Armenia & 0.2838 & 0.2835 & 0.2780 & 0.2859 & 0.2837 & 0.2894 & 0.3056 & 0.3305 & 0.3574 & 0.3738 & 0.4023 & 0.4225 & 0.4484 & 0.4499 & 0.2841 & 0.3863 & 0.3425 \\
\hline Azerbaijan & 3460 & 0.3315 & 0.3212 & 0.3318 & 0.3393 & 0.3659 & 0.3906 & 0.4020 & 0.4010 & 0.3979 & 0.4749 & 0.6114 & 0.7439 & 0.8093 & 0.3393 & 0.5289 & 0.4476 \\
\hline Belarus & 0.6338 & 0.6333 & 0.6703 & 0.6882 & 0.6743 & 0.6786 & 0.6872 & 0.6989 & 0.7209 & 0.7702 & 0.7961 & 0.8228 & 0.8344 & 0.8520 & 0.6631 & 0.7728 & 0.7258 \\
\hline Estonia & 0.5193 & 0.4944 & 0.5097 & 0.4935 & 0.4610 & 0.4675 & 0.4738 & 0.4783 & 0.4816 & 0.4869 & 0.5019 & 0.5229 & 0.5247 & 0.4880 & 0.4909 & 0.4948 & 0.4931 \\
\hline Georgia & 0.4188 & 0.4288 & 0.4455 & 0.4228 & 0.3991 & 0.3814 & 0.3847 & 0.3865 & 0.4167 & 0.4264 & 0.4511 & 0.4786 & 0.5193 & 0.5250 & 0.4161 & 0.4485 & 0.4346 \\
\hline Kazakhstan & 0.6300 & 0.6104 & 0.6003 & 0.5732 & 0.5669 & 0.6010 & 0.6531 & 0.6832 & 0.7188 & 0.7553 & 0.7774 & 0.7979 & 0.8031 & 0.7746 & 0.5970 & 0.7454 & 0.6818 \\
\hline Kyrgyzstan & 0.2162 & 0.2240 & 0.2412 & 0.2458 & 0.2501 & 0.2556 & 0.2628 & 0.2637 & 0.2843 & 0.3064 & 0.3109 & 0.3176 & 0.3382 & 0.3570 & 0.2388 & 0.3051 & 0.2767 \\
\hline Lithuania & 0.9513 & 0.9463 & 0.9504 & 0.9462 & 0.8962 & 0.8985 & 0.9128 & 0.9199 & 0.9388 & 0.9669 & 0.9601 & 0.9627 & 0.9656 & 0.9616 & 0.9315 & 0.9485 & 0.9412 \\
\hline Latvia & 0.8353 & 0.7995 & 0.7977 & 0.7596 & 0.7294 & 0.7274 & 0.7321 & 0.7359 & 0.7526 & 0.7619 & 0.7884 & 0.8213 & 0.8533 & 0.7835 & 0.7748 & 0.7786 & 0.7770 \\
\hline Moldova & 0.2468 & 0.2246 & 0.2209 & 0.2007 & 0.1865 & 0.1890 & 0.1994 & 0.2138 & 0.2202 & 0.2351 & 0.2484 & 0.2535 & 0.2530 & 0.2640 & 0.2114 & 0.2359 & 0.2254 \\
\hline Russia & 0.9798 & 0.9705 & 0.9605 & 0.9159 & 0.9203 & 0.9325 & 0.9315 & 0.9295 & 0.9398 & 0.9484 & 0.9476 & 0.9495 & 0.9483 & 0.9544 & 0.9466 & 0.9436 & 0.9449 \\
\hline Tajikistan & 0.1821 & 0.1440 & 0.1486 & 0.1558 & 0.1601 & 0.1795 & 0.2001 & 0.2290 & 0.2604 & 0.2971 & 0.3208 & 0.2955 & 0.3044 & 0.3337 & & 0.2801 & 0.2294 \\
\hline Turkmenistan & 0.2870 & 0.2816 & 0.2390 & 0.2400 & 0.2643 & 0.2695 & 0.2734 & 0.2681 & 0.2731 & 0.2952 & 0.3417 & 0.3927 & 0.4582 & 0.5201 & 0.2636 & 0.3528 & 0.3146 \\
\hline Ukraine & 0.9117 & 0.8171 & 0.7814 & 0.7498 & 0.7273 & 0.7573 & 0.8133 & 0.8293 & 0.8849 & 0.9318 & 0.9221 & 0.9415 & 0.9513 & 0.9415 & 0.7908 & 0.9020 & 0.8543 \\
\hline Uzbekistan & 0.7697 & & & & & 0.6852 & 0.6930 & & & & 0.8044 & & & & & & 0.7606 \\
\hline Mean A & 0.5474 & 0.5269 & 0.5239 & 0.5129 & 0.5028 & 0.5119 & 0.5276 & 0.5383 & 0.5586 & 0.5815 & 0.6032 & 0.6300 & 0.6573 & 0.6641 & 0.5210 & 0.5951 & 0.5633 \\
\hline Mean RR & 0.6025 & 0.5817 & 0.5628 & 0.5490 & 0.5549 & 0.5708 & 0.5883 & 0.5976 & 0.6123 & 0.6333 & 0.6692 & 0.7221 & 0.7733 & 0.8009 & 0.5703 & 0.6746 & 0.6299 \\
\hline Mean NRR & 0.5199 & 0.4996 & 0.5044 & 0.4948 & 0.4768 & 0.4824 & 0.4972 & 0.5086 & 0.5318 & 0.5556 & 0.5702 & 0.5839 & 0.5992 & 0.5956 & 0.4963 & 0.5553 & 0.5300 \\
\hline GDP $<2.5 \%$ & 0.5073 & 0.4761 & 0.4705 & 0.4536 & 0.4489 & 0.4628 & 0.4814 & 0.4931 & 0.5179 & 0.5438 & 0.5499 & 0.5515 & 0.5591 & 0.5701 & 0.4699 & 0.5334 & 0.5061 \\
\hline GDP $2.5-5.0 \%$ & 0.6306 & 0.6136 & 0.6132 & 0.6009 & 0.5843 & 0.5886 & 0.6013 & 0.6095 & 0.6289 & 0.6540 & 0.6776 & 0.7072 & 0.7339 & 0.7314 & 0.6052 & 0.6680 & 0.6411 \\
\hline GDP $>5.0 \%$ & 0.3149 & 0.3075 & 0.2996 & 0.3089 & 0.3115 & 0.3277 & 0.3481 & 0.3662 & 0.3792 & 0.3858 & 0.4386 & 0.5170 & 0.5962 & 0.6296 & 0.3117 & 0.4576 & 0.3951 \\
\hline $\mathrm{GDP}<4.0 \%$ & 0.4469 & 0.3952 & 0.3837 & 0.3688 & 0.3580 & 0.3753 & 0.4043 & 0.4240 & 0.4552 & 0.4880 & 0.4971 & 0.4968 & 0.5029 & 0.5131 & 0.3880 & 0.4727 & 0.4364 \\
\hline GDP $4.0-8.0 \%$ & 0.6241 & 0.6103 & 0.6108 & 0.5969 & 0.5845 & 0.5897 & 0.6004 & 0.6070 & 0.6255 & 0.6487 & 0.6680 & 0.6925 & 0.7158 & 0.7163 & 0.6027 & 0.6593 & 0.6350 \\
\hline GDP $>8.0 \%$ & 0.3149 & 0.3075 & 0.2996 & 0.3089 & 0.3115 & 0.3277 & 0.3481 & 0.3662 & 0.3792 & 0.3858 & 0.4386 & 0.5170 & 0.5962 & 0.6296 & 0.3117 & 0.4576 & 0.3951 \\
\hline
\end{tabular}

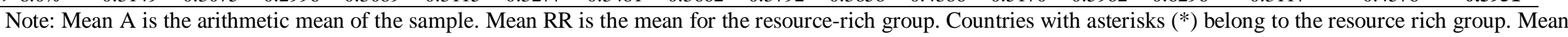

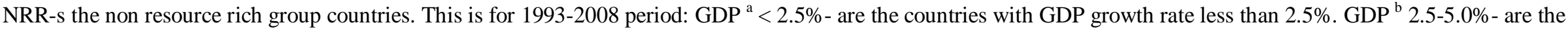

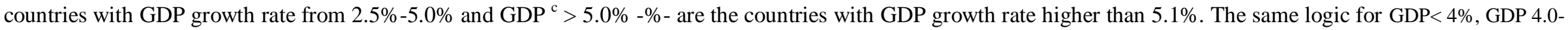
$8.0 \%$ and GDP $>8.0 \%$ and it is for the $1995-2008$ period. Source: own calculations. 
Table A.3. Efficiency Change (EC) for the 15 FSU countries.

\begin{tabular}{|c|c|c|c|c|c|c|c|c|c|c|c|c|c|c|c|c|}
\hline EC & 1996 & 1997 & 1998 & 1999 & 2000 & 2001 & 2002 & 2003 & 2004 & 2005 & 2006 & 2007 & 2008 & $1995-2000$ & 2001-2008 & Mean A \\
\hline Armenia & 0.9991 & 0.9803 & 1.0287 & 0.9923 & 1.0199 & 1.0558 & 1.0815 & 1.0815 & 1.0459 & 1.0763 & 1.0502 & 1.0613 & 1.0033 & 1.0041 & 1.0570 & 1.0366 \\
\hline Azerbaijan & 0.9580 & 0.9689 & 1.0331 & 1.0226 & 1.0783 & 1.0676 & 1.0290 & & 0.9922 & 1.1934 & 1.2875 & 1.2167 & 1.0879 & 1.0122 & 1.1090 & 1.0718 \\
\hline Belarus & 0.9992 & 1.0584 & 1.0266 & 0.9798 & 1.0064 & 1.0126 & 1.0172 & 1.0313 & 1.0684 & 1.0337 & 1.0335 & 1.0141 & 1.0212 & 1.0141 & 1.0290 & 1.0233 \\
\hline Estonia & 0.9520 & 1.0309 & 0.9682 & 0.9343 & 1.0141 & 1.0135 & 1.0094 & 1.0070 & 1.0108 & 1.0310 & 1.0418 & 1.0033 & 0.9302 & 0.9799 & 1.0059 & 0.9959 \\
\hline Georgia & 1.0240 & 1.0389 & 0.9490 & 0.9440 & 0.9556 & 1.0087 & 1.0047 & 1.0780 & 1.0233 & 1.0579 & 1.0609 & & & & & 1.0186 \\
\hline Kazakhstan & 0.9690 & 0.9834 & 0.9548 & 0.9892 & 1.0600 & 1.0868 & 1.0461 & 1.0521 & 1.0507 & 1.0292 & 1.0265 & 1.0065 & 0.9645 & 0.9913 & 1.0328 & 1.0168 \\
\hline Kyrgyzstan & 1.0360 & 1.0768 & 1.0190 & 1.0173 & 1.0222 & 1.0279 & 1.0036 & 1.0783 & 1.0777 & 1.0147 & 1.0216 & 1.0648 & 1.0556 & 1.0343 & 1.0430 & 1.0396 \\
\hline Lithuania & 0.9947 & 1.0044 & 0.9956 & 0.9471 & 1.0026 & 1.0159 & 1.0078 & 1.0206 & 1.0299 & 0.9930 & 1.0027 & 1.0030 & 0.9959 & 0.9889 & 1.0086 & 1.0010 \\
\hline Latvia & 0.9572 & 0.9978 & 0.9522 & 0.9603 & 0.9973 & 1.0064 & 1.0051 & 1.0227 & 1.0123 & 1.0348 & 1.0418 & 1.0389 & 0.9182 & & 1.0100 & 0.9958 \\
\hline Moldova & 0.9101 & 0.9835 & 0.9087 & 0.9293 & 1.0134 & 1.0551 & 1.0722 & 1.0298 & 1.0678 & 1.0564 & 1.0206 & 0.9982 & 1.0432 & 0.9490 & 1.0429 & 1.0068 \\
\hline Russia & 0.9906 & 0.9897 & & 1.0049 & 1.0132 & 0.9989 & 0.9979 & 1.0111 & 1.0091 & 0.9991 & 1.0021 & & 1.0064 & & & 0.9981 \\
\hline Tajikistan & 0.7911 & 1.0319 & 1.0483 & 1.0273 & 1.1213 & 1.1147 & 1.1447 & 1.1372 & 1.1407 & 1.0798 & 0.9211 & 1.0304 & 1.0962 & 1.0040 & 1.0831 & 1.0527 \\
\hline Turkmenistan & 0.9811 & 0.8488 & 1.0044 & 1.1012 & 1.0197 & 1.0142 & 0.9808 & 1.0184 & 1.0809 & 1.1578 & 1.1492 & 1.1667 & 1.1352 & & & 1.0506 \\
\hline Ukraine & & 0.9564 & 0.9596 & 0.9699 & & 1.0739 & & & & 0.9895 & & & & & 1.0280 & 1.0037 \\
\hline Uzbekistan & 0.9281 & 0.9703 & 0.9866 & 0.9994 & 1.0025 & 1.0115 & 1.0178 & 1.0329 & 1.0563 & 1.0452 & 1.0677 & 1.0630 & 1.0365 & 0.9774 & 1.0414 & 1.0167 \\
\hline Mean A & 0.9591 & 0.9947 & 0.9859 & 0.9879 & 1.0245 & 1.0376 & 1.0292 & 1.0444 & 1.0479 & 1.0528 & 1.0499 & 1.0507 & 1.0197 & 0.9904 & 1.0415 & 1.0219 \\
\hline Mean RR & 0.9654 & 0.9522 & 0.9865 & 1.0235 & 1.0347 & 1.0358 & 1.0143 & 1.0225 & 1.0378 & 1.0849 & 1.1066 & 1.0903 & 1.0461 & 0.9925 & 1.0548 & 1.0308 \\
\hline Mean NRR & 0.9560 & & & & & & & & & & & & & & & 1.0174 \\
\hline $\mathrm{GDP}<2.5 \%$ & 0.9248 & 1.0076 & 0.9778 & 0.9897 & 1.0423 & 1.0541 & 1.0476 & 1.0647 & 1.0697 & 1.0279 & 0.9973 & 1.0205 & 1.0382 & & 1.0400 & 1.0202 \\
\hline GDP $2.5-5.0 \%$ & 0.9757 & 0.9916 & 0.9797 & 0.9819 & 1.0073 & 1.0212 & 1.0111 & 1.0329 & 1.0416 & 1.0478 & 1.0530 & 1.0476 & 1.0016 & 0.9872 & 1.0321 & 1.0148 \\
\hline GDP $>5.0 \%$ & 0.9786 & 0.9746 & 1.0309 & 1.0075 & 1.0491 & 1.0617 & 1.0552 & 1.0396 & 1.0190 & 1.1349 & 1.1689 & 1.1390 & 1.0456 & 1.0081 & 1.0830 & 1.0542 \\
\hline $\mathrm{GDP}<4.0 \%$ & 0.8658 & 0.9906 & 0.9722 & 0.9755 & 1.0587 & 1.0812 & 1.0788 & 1.0780 & 1.0872 & 1.0419 & 0.9876 & 1.0130 & 1.0431 & 0.9725 & 1.0513 & 1.0210 \\
\hline GDP $4.0-8.0 \%$ & 0.9832 & 0.9999 & 0.9810 & 0.9878 & 1.0093 & 1.0197 & 1.0090 & 1.0352 & 1.0419 & 1.0396 & 1.0448 & 1.0444 & 1.0075 & 0.9922 & 1.0303 & 1.0156 \\
\hline GDP $>8.0 \%$ & 0.9786 & 0.9746 & 1.0309 & 1.0075 & 1.0491 & 1.0617 & 1.0552 & 1.0396 & 1.0190 & 1.1349 & 1.1689 & 1.1390 & 1.0456 & 1.0081 & 1.0830 & 1.0542 \\
\hline
\end{tabular}

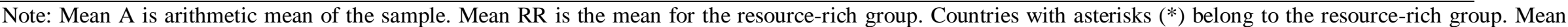

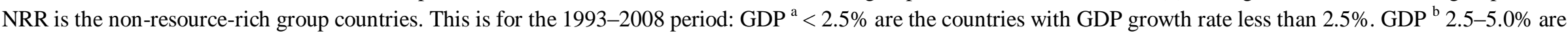

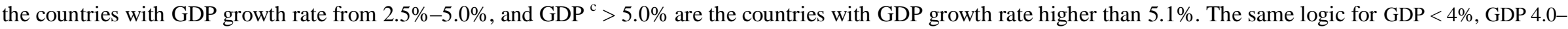
$8.0 \%$, and GDP $>8.0 \%$, and it is for the 1995-2008 period. Source: own calculations. 
Table A.4. Technical Change (TC) for the 15 FSU Countries

\begin{tabular}{|c|c|c|c|c|c|c|c|c|c|c|c|c|c|c|c|c|}
\hline TC & 1996 & 1997 & 1998 & 1999 & 2000 & 2001 & 2002 & 2003 & 2004 & 2005 & 2006 & 2007 & 2008 & 1995-2000 & 2001-2008 & Mean A \\
\hline Armenia & 0.9919 & 0.9920 & 0.9916 & 0.9909 & 0.9899 & 0.9888 & 0.9878 & 0.9874 & 0.9870 & 0.9868 & 0.9870 & 0.9874 & 0.9876 & 0.9912 & 0.9875 & 0.9889 \\
\hline Azerbaijan & 1.0037 & 1.0039 & 1.0040 & 1.0031 & 1.0012 & 0.9992 & 0.9979 & 0.9982 & 0.9992 & 0.9993 & 0.9983 & 0.9967 & 0.9946 & 1.0032 & 0.9979 & 0.9999 \\
\hline Belarus & 1.0190 & 1.0180 & 1.0171 & 1.0159 & 1.0143 & 1.0124 & 1.0103 & 1.0084 & 1.0069 & 1.0057 & 1.0049 & 1.0045 & 1.0042 & 1.0169 & 1.0072 & 1.0109 \\
\hline Estonia & 1.0221 & 1.0233 & 1.0244 & 1.0247 & 1.0241 & 1.0234 & 1.0229 & 1.0223 & 1.0215 & 1.0207 & 1.0199 & 1.0191 & 1.0178 & 1.0237 & 1.0210 & 1.0220 \\
\hline Georgia & 0.9897 & 0.9910 & 0.9922 & 0.9933 & 0.9936 & 0.9932 & 0.9924 & 0.9914 & 0.9905 & 0.9897 & 0.9885 & 0.9872 & 0.9857 & 0.9919 & 0.9898 & 0.9906 \\
\hline Kazakhstan & 1.0299 & 1.0276 & 1.0251 & 1.0225 & 1.0200 & 1.0177 & 1.0157 & 1.0137 & 1.0120 & 1.0107 & 1.0098 & 1.0092 & 1.0084 & 1.0250 & 1.0122 & 1.0171 \\
\hline Kyrgyzstan & 0.9870 & 0.9858 & 0.9836 & 0.9815 & 0.9799 & 0.9784 & 0.9764 & 0.9741 & 0.9717 & 0.9693 & 0.9672 & 0.9657 & 0.9642 & 0.9836 & 0.9709 & 0.9758 \\
\hline Lithuania & 1.0206 & 1.0212 & 1.0218 & 1.0218 & 1.0209 & 1.0198 & 1.0187 & 1.0172 & 1.0161 & 1.0154 & 1.0147 & 1.0140 & 1.0131 & 1.0213 & 1.0161 & 1.0181 \\
\hline Latvia & 1.0099 & 1.0111 & 1.0128 & 1.0142 & 1.0147 & 1.0146 & 1.0139 & 1.0133 & 1.0130 & 1.0128 & 1.0125 & 1.0119 & 1.0106 & 1.0125 & 1.0128 & 1.0127 \\
\hline Moldova & 0.9963 & 0.9955 & 0.9945 & 0.9929 & 0.9908 & 0.9886 & 0.9867 & 0.9852 & 0.9840 & 0.9830 & 0.9819 & 0.9808 & 0.9798 & 0.9940 & 0.9838 & 0.9877 \\
\hline Russia & 1.0413 & 1.0394 & 1.0370 & 1.0344 & 1.0320 & 1.0297 & 1.0275 & 1.0254 & 1.0236 & 1.0218 & 1.0201 & 1.0187 & 1.0175 & 1.0368 & 1.0231 & 1.0284 \\
\hline Tajikistan & 0.9870 & 0.9855 & 0.9832 & 0.9808 & 0.9777 & 0.9741 & 0.9707 & 0.9674 & 0.9645 & 0.9616 & 0.9590 & 0.9567 & 0.9547 & 0.9828 & 0.9636 & 0.9710 \\
\hline Turkmenistan & 1.0186 & 1.0190 & 1.0183 & 1.0171 & 1.0152 & 1.0128 & 1.0101 & 1.0071 & 1.0032 & 0.9984 & 0.9938 & 0.9891 & 0.9849 & 1.0177 & 0.9999 & 1.0068 \\
\hline Ukraine & 1.0249 & 1.0223 & 1.0197 & 1.0171 & 1.0146 & 1.0122 & 1.0098 & 1.0076 & 1.0057 & 1.0039 & 1.0023 & 1.0010 & 0.9999 & 1.0197 & 1.0053 & 1.0108 \\
\hline Uzbekistan & 1.0023 & 1.0025 & 1.0015 & 0.9997 & 0.9975 & 0.9951 & 0.9926 & 0.9898 & 0.9870 & 0.9844 & 0.9816 & 0.9788 & 0.9764 & 1.0007 & 0.9857 & 0.9915 \\
\hline Mean A & 1.0096 & 1.0092 & 1.0084 & 1.0073 & 1.0058 & 1.0040 & 1.0022 & 1.0006 & 0.9991 & 0.9976 & 0.9961 & 0.9947 & 0.9933 & 1.0081 & 0.9984 & 1.0021 \\
\hline Mean RR & 1.0192 & 1.0185 & 1.0172 & 1.0154 & 1.0132 & 1.0109 & 1.0088 & 1.0069 & 1.0050 & 1.0029 & 1.0007 & 0.9985 & 0.9963 & 1.0167 & 1.0038 & 1.0087 \\
\hline Mean NRR & 1.0048 & 1.0046 & 1.0041 & 1.0033 & 1.0020 & 1.0005 & 0.9990 & 0.9974 & 0.9961 & 0.9949 & 0.9938 & 0.9928 & 0.9917 & 1.0038 & 0.9958 & 0.9989 \\
\hline GDP $<2.5 \%$ & 1.0073 & 1.0057 & 1.0036 & 1.0013 & 0.9990 & 0.9966 & 0.9942 & 0.9920 & 0.9899 & 0.9879 & 0.9861 & 0.9846 & 0.9832 & 1.0034 & 0.9893 & 0.9947 \\
\hline GDP $2.5-5.0 \%$ & 1.0140 & 1.0142 & 1.0141 & 1.0137 & 1.0125 & 1.0111 & 1.0096 & 1.0079 & 1.0063 & 1.0047 & 1.0032 & 1.0017 & 1.0001 & 1.0137 & 1.0056 & 1.0087 \\
\hline GDP $>5.0 \%$ & 0.9978 & 0.9980 & 0.9978 & 0.9970 & 0.9956 & 0.9940 & 0.9928 & 0.9928 & 0.9931 & 0.9930 & 0.9927 & 0.9921 & 0.9911 & 0.9972 & 0.9927 & 0.9944 \\
\hline $\mathrm{GDP}<4.0 \%$ & 1.0027 & 1.0011 & 0.9991 & 0.9969 & 0.9943 & 0.9917 & 0.9891 & 0.9867 & 0.9847 & 0.9828 & 0.9810 & 0.9795 & 0.9781 & 0.9988 & 0.9842 & 0.9898 \\
\hline GDP $4.0-8.0 \%$ & 1.0140 & 1.0139 & 1.0134 & 1.0125 & 1.0112 & 1.0097 & 1.0081 & 1.0063 & 1.0045 & 1.0029 & 1.0013 & 0.9998 & 0.9983 & 1.0130 & 1.0039 & 1.0074 \\
\hline GDP $>8.0 \%$ & 0.9978 & 0.9980 & 0.9978 & 0.9970 & 0.9956 & 0.9940 & 0.9928 & 0.9928 & 0.9931 & 0.9930 & 0.9927 & 0.9921 & 0.9911 & 0.9972 & 0.9927 & 0.9944 \\
\hline
\end{tabular}

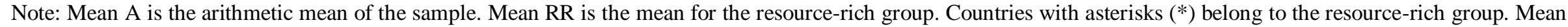

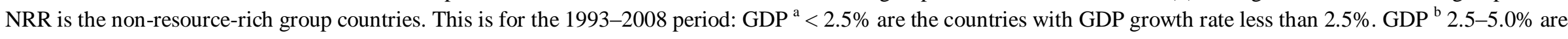

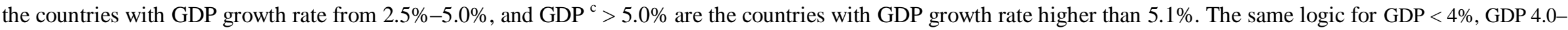
$8.0 \%$, and GDP $>8.0 \%$, and it is for the 1995-2008 period. Source: own calculations. 
Table A.5. Total Factor Productivity (TFP) Change for the 15 FSU Countries

\begin{tabular}{|c|c|c|c|c|c|c|c|c|c|c|c|c|c|c|c|c|}
\hline TFP & 1996 & 997 & 1998 & 1999 & 2000 & 2001 & 2002 & 2003 & 2004 & 2005 & 2006 & 2007 & 2008 & $1995-2000$ & 2001-2008 & Mean A \\
\hline Armenia & 0.9910 & 0.9725 & 1.0201 & 0.9833 & 1.0096 & 1.0440 & 1.0683 & 1.0678 & 1.0323 & 1.0621 & 1.0366 & 1.0479 & 0.9908 & 0.9953 & 1.0437 & 1.0251 \\
\hline Azerbaijan & 9615 & 0.9727 & 1.0373 & 1.0257 & 1.0797 & 1.0667 & 1.0268 & 0.9959 & 0.9914 & 1.1926 & 1.2853 & 1.2127 & 1.0820 & 1.0154 & 1.1067 & 1.0716 \\
\hline Belarus & 1.0182 & 1.0775 & 1.0442 & 0.9954 & 1.0208 & 1.0252 & 1.0276 & 1.0400 & 1.0758 & 1.0396 & 1.0386 & 1.0186 & 1.0254 & 1.0312 & 1.0364 & 1.0344 \\
\hline Estonia & 0.9730 & 1.0549 & 0.9918 & 0.9573 & 1.0385 & 1.0372 & 1.0325 & 1.0295 & 1.0326 & 1.0524 & 1.0626 & 1.0225 & 0.9467 & 1.0031 & 1.0270 & 1.0178 \\
\hline Georgia & 1.0134 & 1.0295 & 0.9416 & 0.9377 & 0.9495 & 1.0018 & 0.9971 & 1.0687 & 1.0136 & & & & & & & 1.0089 \\
\hline Kazakhstan & 0.9980 & 1.0105 & 0.9788 & 1.0115 & 1.0812 & 1.1061 & 1.0625 & 1.0666 & 1.0633 & 1.0402 & 1.0365 & 1.0158 & 0.9726 & 1.0160 & 1.0454 & 1.0341 \\
\hline Kyrgyzstan & 1.0226 & 1.0615 & 1.0023 & 0.9985 & 1.0016 & 1.0056 & 0.9799 & 1.0504 & 1.0472 & 0.9835 & 0.9881 & 1.0283 & 1.0178 & 1.0173 & 1.0126 & 1.0144 \\
\hline Lithuania & 1.0152 & 1.0256 & 1.0174 & 0.9678 & 1.0235 & 1.0360 & 1.0266 & 1.0381 & 1.0464 & 1.0083 & 1.0174 & 1.0171 & 1.0090 & 1.0099 & 1.0249 & 1.0191 \\
\hline Latvia & 0.9666 & 1.0089 & 0.9644 & 0.9739 & 1.0119 & 1.0211 & 1.0192 & 1.0363 & 1.0255 & 1.0480 & 1.0548 & 1.0512 & 0.9279 & & 1.0230 & 1.0084 \\
\hline Moldova & 0.9067 & 0.9791 & 0.9037 & 0.9227 & 1.0040 & 1.0431 & 1.0579 & 1.0145 & 1.0507 & 1.0384 & 1.0021 & 0.9790 & 1.0221 & 0.9432 & 1.0260 & 0.9942 \\
\hline Russia & 1.0315 & 1.0287 & 0.9888 & 1.0395 & 1.0456 & 1.0287 & 1.0253 & 1.0369 & 1.0329 & & 1.0223 & & 1.0240 & & 1.0260 & 1.0263 \\
\hline Tajikistan & 0.7808 & 1.0169 & 1.0307 & 1.0075 & 1.0962 & 1.0858 & 1.1111 & 1.1001 & 1.1002 & 1.0383 & 0.8833 & 0.9858 & 1.0466 & 0.9864 & 1.0439 & 1.0218 \\
\hline Turkmenistan & 0.9994 & 0.8649 & 1.0228 & 1.1200 & 1.0353 & 1.0273 & 0.9907 & 1.0257 & 1.0843 & 1.1560 & 1.1420 & & & & 1.0873 & 1.0570 \\
\hline Ukraine & & 0.9777 & & 0.9865 & 1.0565 & & & & & & & & & & & 1.0143 \\
\hline Uzbekistan & 0.9302 & 0.9727 & 0.9880 & 0.9992 & 1.0000 & 1.0065 & 1.0103 & 1.0224 & 1.0425 & 1.0289 & 1.0480 & 1.0405 & 1.0120 & 0.9780 & 1.0264 & 1.0078 \\
\hline Mean A & 0.9685 & 1.0036 & 0.9940 & 0.9951 & 1.0303 & 1.0415 & 1.0310 & 1.0445 & 1.0465 & 1.0500 & 1.0460 & 1.0449 & 1.0121 & 0.9983 & 1.0396 & 1.0237 \\
\hline Mean RR & 0.9841 & 0.9699 & 1.0031 & 1.0392 & 1.0483 & 1.0470 & 1.0231 & 1.0295 & 1.0429 & 1.0877 & 1.1068 & 1.0881 & 1.0417 & 1.0089 & 1.0584 & 1.0394 \\
\hline Mean NRR & 0.9606 & & & & & & & & & & & & & & 1.0302 & 1.0158 \\
\hline $\mathrm{GDP}<2.5 \%$ & 0.9320 & 1.0128 & 0.9808 & 0.9909 & 1.0408 & 1.0500 & 1.0408 & 1.0554 & 1.0580 & 1.0149 & 0.9838 & 1.0044 & 1.0200 & 0.9915 & 1.0284 & 1.0142 \\
\hline GDP $2.5-5.0 \%$ & 0.9893 & 1.0056 & 0.9936 & 0.9954 & 1.0201 & 1.0327 & 1.0208 & 1.0409 & 1.0480 & 1.0525 & 1.0561 & & 1.0010 & 1.0008 & 1.0376 & 1.0234 \\
\hline GDP $>5.0 \%$ & 0.9763 & 0.9726 & 1.0287 & 1.0045 & 1.0446 & 1.0553 & 1.0475 & 1.0318 & 1.0119 & 1.1273 & 1.1610 & 1.1303 & 1.0364 & 1.0053 & 1.0752 & 1.0483 \\
\hline $\mathrm{GDP}<4.0 \%$ & 0.8687 & 0.9912 & 0.9709 & 0.9722 & 1.0523 & 1.0720 & 1.0662 & 1.0633 & 1.0700 & 1.0234 & 0.9696 & 0.9921 & 1.0194 & 0.9711 & 1.0345 & 1.0101 \\
\hline GDP $4.0-8.0 \%$ & 0.9968 & 1.0135 & 0.9940 & 1.0001 & 1.0208 & 1.0296 & 1.0172 & 1.0415 & 1.0464 & 1.0425 & 1.0459 & 1.0437 & 1.0050 & 1.0050 & 1.0340 & 1.0228 \\
\hline GDP $>8.0 \%$ & 0.9763 & 0.9726 & 1.0287 & 1.0045 & 1.0446 & 1.0553 & 1.0475 & 1.0318 & 1.0119 & 1.1273 & 1.1610 & 1.1303 & 1.0364 & 1.0053 & 1.0752 & 1.0483 \\
\hline
\end{tabular}

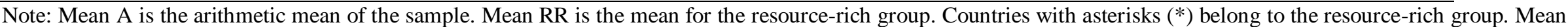

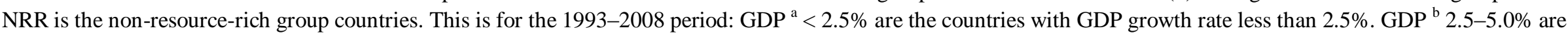

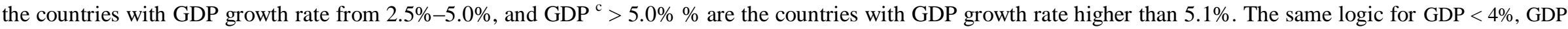
$4.0-8.0 \%$, and GDP $>8.0 \%$, and it is for the 1995-2008 period. Source: own calculations. 


\section{Notes}

'FSU economies in our study consist of: Armenia (ARM), Azerbaijan (AZE), Belarus (BLR), Estonia (EST), Georgia (GEO), Kazakhstan (KAZ), Kyrgyzstan (KGZ), Lithuania (LTU), Latvia (LVA), Moldova (MDA), Russian Federation (RUS), Tajikistan (TJK), Turkmenistan (TKM), Ukraine (UKR) and Uzbekistan (UZB). Country nomenclature and country codes in brackets are from the World Bank.

ii The World Bank online database (2010) reports that the average yearly value of real GDP per capita in thousands of U.S. dollars for the period 1993-2007 of Estonia (6,153.58, highest) is twenty-seven-fold higher than that of Tajikistan (192.43, lowest).

iii Furthermore, the non-parametric approach is deterministic and, hence, it does not take into account the impact of random shocks in the production model.

iv The findings of Hoekman et al. (2004) identify three channels of technology transfer that could boost economic growth and convergence of poor countries toward developed economies: (1) trade in goods and services, (2) foreign domestic investment (FDI), and (3) trade in knowledge via technology licensing. The theoretical foundations of international technology transfer were established by Romer (1990), Grossman and Helpman (1991, 1993), and Aghion and Howitt (1992). FDI is associated with fostering economic growth in the presence of certain economic, financial, and institutional characteristics of recipient countries (Ellingstad, 1997; Dunning, 1993, 1998; Borensztein et.al, 1998; Barrel and Holland, 2000; Blomström et al., 2001; Konings, 2001; Lipsey, 2002; Jensen, 2006; Navaretti and Venables, 2004; and Büthe, 2008).

'Economists' early notable contributions to the theory and formation of human capital on the micro level were brought by Mincer (1958), Schultz (1960), Denison (1962), and Becker (1975).

${ }^{\mathrm{vi}}$ For example, De Broeck and Koen (2000) report -6.6\% TFP growths for FSU countries between 1991-1997, and Deliktas and Balcilar (2005) found -2\% for 25 transition economies, including FSU, for 1991-2000.

vii Absorptive capacity is considered an important component in technology adoption and diffusion from developed countries. Previous studies point out that on the level of economic development, human capital resources and business environment are factors affecting absorptive capacity. For a more detailed discussion, please consult Benhabib and Spiegel (1994), Xu (2000), Eaton and Kortum (2001), Keller (2004), Nunnenkamp (2004), Kneller, (2005), Kneller and Stevens (2006). According to international trade theory, openness to trade positively contributes to economic growth and reduces barriers to technology adoption that are major factors in differences in per capita income (Parente and Prescott, 1994). The recent study by Calderón and Poggio (2010) finds support for the positive impact of trade on the economic growth of 160 countries over 1960-2010.

${ }^{\text {viii }}$ We do not use local $R \& D$ investment due to unsystematic reforms in the R\&D sector in FSU countries (see Yegorov (2009) for Russia and Ukraine) and problems with lack of data. However, looking at most of our FSU countries we could see that R\&D investments were scarce.

${ }^{\text {ix }}$ For a comprehensive review of stochastic production functions, see Førsund, Lovell, and Schmidt (1980). Schmidt and Sickles (1984) and Atkinson and Cornwell (1994, 1994a) address modeling and estimation of SFA for panel data production frontiers.

${ }^{\mathrm{x}} \omega_{\text {it }}$ are random disturbances that follow truncated normal or half-normal distribution, $N\left(0, \sigma^{2}\right)$, so that the truncation point is $-\delta \mathbf{Z}_{\mathrm{it}}$, making $\omega_{\mathrm{it}} \geq-\delta \mathbf{Z}_{\mathrm{it}}$. According to Battese and Coelli (1995), this condition should be maintained for $u_{\mathrm{it}}$ to be a non-negative truncation of the $N\left(\delta \boldsymbol{Z}_{i t}, \sigma_{u}{ }^{2}\right)$.

${ }^{x i}$ Sachs and Warner's $(1995,2001)$ papers spurred research on the natural-resource curse hypothesis or whether resource richness is stopping increased productivity and economic growth in developing countries. In relation to transition economies, this phenomenon is considered to bring negative effects on economic growth, but empirical research points to differentiated conclusions that are often against resource curse and in favor of resource dependence (Neumayer, 2004; Bulte etal, 2005; Stijns, 2005, 2006; Brunnschweiler, 2008; Brunnschweiler and Bulte, 2008; Murshed and Serino, 2011).

${ }^{x i i}$ We have five resource-rich (RR) countries (that are considered energy exporters) in our study—i.e., Russia, Azerbaijan, Kazakhstan, Turkmenistan, and Uzbekistan. This leaves ten countries as non-resource-rich (NRR). We classify our sample based solely on petroleum and gas possessions. As stated by Sachs and Warner (2001), the rents obtained from oil and gas exports may induce rent seeking and possible corruption from government officials rather than pro-growth reforms.

xiii Nishimizu and Page (1982) show another formulation of the technical change index in which instead of the geometric mean they use the arithmetic mean. Furthermore, they calculate TC using a deterministic frontier. Our measure is for the stochastic frontier approach, which was also used in the recent study by Seo et al. (2010), where the authors justify the use of the geometric mean due to the fact that the technological change is considered firm 
specific. Their intuition is that technology is common to all firms, but a change in technology affects each firm differently if the production frontier does not shift in a parallel manner.

${ }^{\text {xiv }}$ We assume that the difference between $T E$ at $t-1$ and $T E$ at $t$ is negative.

${ }^{\mathrm{xv}}$ Initial conditions are an important factor and should be taken into account when comparing countries that had similar historical and socioeconomic development. In a sense, this helps to reduce disparity in unobserved intrinsic country effects.

${ }^{\text {xvi }}$ Since our sample starts from 1995, we begin measuring the capital accumulation from 1992 using a

$10 \%$ depreciation rate for capital. For $\mathrm{K}_{\mathrm{i} 1992}$, we had to depreciate $\mathrm{I}_{\mathrm{i} 1992}$ only due to the unavailability of statistics for $\mathrm{K}_{1991}$. We underline that FSU economies experienced physical capital destruction during transition to independence in 1991 and had to build or re-build most of physical capital. Regarding the depreciation rate of capital, for example, $\mathrm{Bu}(2006)$ reports the mean of capital depreciations based on a sample of firms as Cote d'Ivoire (27.3\%), Ghana (34.4\%), Zimbabwe (11.8\%), Kenya(-14.9\%), Indonesia ( 84\%), Philippines (25.8\%), and South Korea (9.3\%). On the other hand, the study by Mastromarco and Ghosh (2009) uses 4\% for 57 developing countries of Africa, Asia, and Latin America. We believe that measurement errors in capital stock are not correlated with efficiency scores as pointed out by Marstromarco and Ghosh (2009, note 16). For that reason, we surmise that our variable captures the major part of its development.

xvii Verdier (2008) studies the factors driving long-term capital flows for the 66 developing countries of Asia and Latin America and uses 3\% for the depreciation rate $\tau$ in the calculation of the accumulated human capital stock variable.

xviii We employed the R software package Frontier written by Tim Coelli and Arne Henningsen to obtain our estimates for 15 FSU countries for the period 1995-2008. For producing graphs and statistical tests, STATA software was utilized.

${ }^{\text {xix }}$ If $\gamma=0$, then it means that all deviations from the stochastic production frontier are due to the statistical noise part of the composite error term $v_{\mathrm{it}}$ of Eq. (1).

${ }^{\mathrm{xx}}$ Notice that we also check whether our translog specification was the best choice (for example, over CobbDouglas) looking at $\sigma^{2}$, that is also significant. This points out that the translog specification of the production function could be used in assessing the inefficiency.

${ }^{x x i}$ For example, a similar result to ours has also been found for other resource-rich countries in previous studies by Brunnschweiler (2008) and Brunnschweiler and Bulte (2008), underlying the positive direct relationship between economic growth and natural resource abundance.

${ }^{x x i i}$ For Model (2) in Table 2, the mean efficiency for the whole sample over 1995-2008 is equal to 0.50, which is slightly lower than from our main model of interest.

${ }_{x x i i i}$ These low technical efficiency scores could also be correlated with the fact that Armenia, Azerbaijan, Georgia, Moldova, Tajikistan, and Ukraine (except Turkmenistan) were involved in prolonged interstate violent conflicts.

${ }^{\text {xxiv }}$ Resource-rich countries are highlighted by an asterisk (*) in Table 5.

${ }^{x x v}$ For a robustness check on the pair-wise rank correlations of real GDP (rGDP) and efficiency estimates, we divided rGDP by its geometric mean and performed our tests again. We observed change neither in significance and magnitudes nor in the signs of variables. 